\title{
PAISAGEM URBANA, CENÁRIO E PERCEPÇÃO A NOÇÃO DE MEMÓRIA COMO COMPONENTE METODOLÓGICA DO PROJETO
}

MARIO CENIQUEL

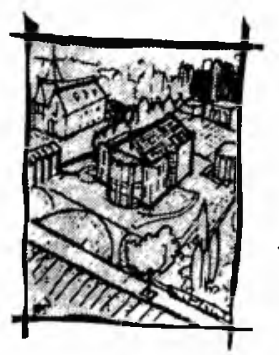

As considerações a serem formuladas no presente artigo se originaram, em grande parte, a partir de uma experiência projetual singular, envolvendo a escavação arqueológica para recuperação do antigo cais da praça XV de Novembro, no centro do decorrentes e adjacentes ${ }^{1}$.

Desenvolvida durante um período maior de um ano entre 1986 e 1988, esta obra surgia como uma das propostas relevantes do Projeto do Corredor Cultu$\mathrm{ral}^{2}$, sendo parte integrante, portanto, de um conjunto maior de obras, inseridas numa das áreas em que tal projeto setoriza o centro e que melhor representa 0 Rio "luso-brasileiro"

Na nossa qualidade de consultores do Diretor da ex-Diretoria Geral de Parques e Jardins (atual Fundação Rio-Parques e Jardins) ligado ao governo municipal, coube-nos, na ocasião, a coordenação geral do projeto de paisagismo e da forma de exibição do sítio arqueológico, em co-gestão com outros órgãos públicos ${ }^{3}$.

Consideramos que a relevância do caso em questão reside tanto nas reflexões que possa suscitar a abordagem adotada para o trato das intervenções na paisagem urbana de interesse histórico, por um ângulo comunicacional, como pelo estudo da relação entre teoria e prática do arquiteto no seio da gestão pública.

Por outro lado, o papel significativo que adquire aquela temática, quando rebatida na cidade do Rio de Janeiro (como decorrência do valor histórico, em escala nacional, do seu patrimônio urbanístico - arquitetônico) acentua o grau de responsabilidade e/ou compromisso das respectivas decisões de projeto.

Naturalmente, sendo a noção de memória o alicerce conceitual básico do assunto em questão - paisagem e história é necessário um aprofundamento mínimo sobre a mesma, que explicite a orientação teórica adotada. 


\section{Praça 15}

Velho cais ressurge com a beleza do perfil original
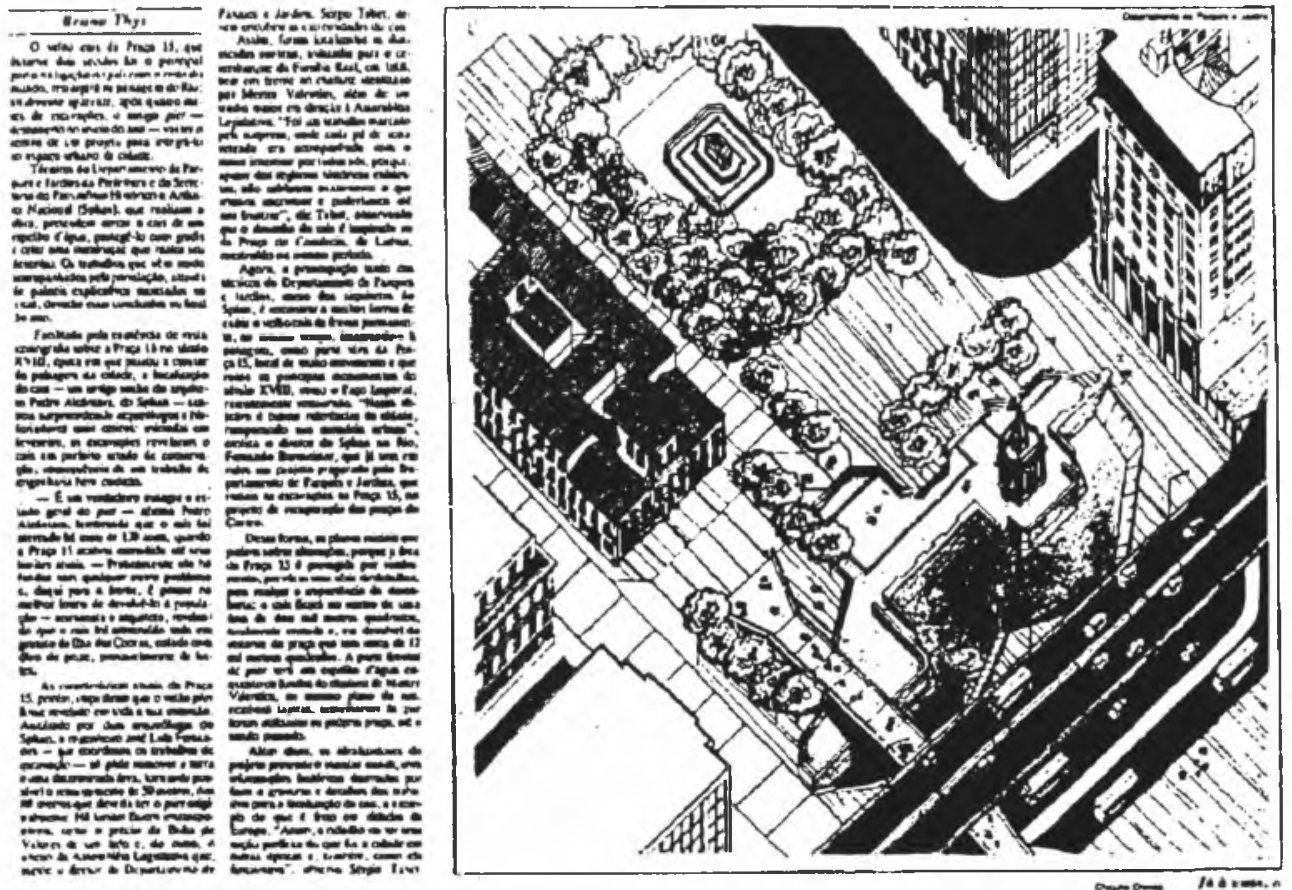

Muitos achados arqueológicos

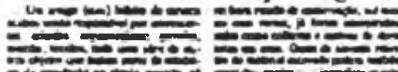

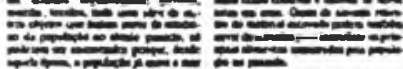
T-

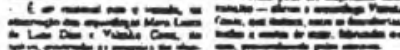
는 $-2=0$

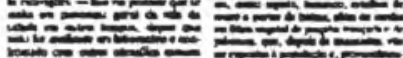

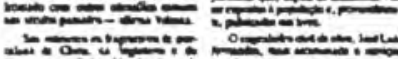
$=0 \div=0$ $2-1=$

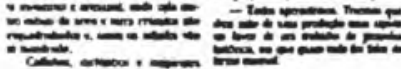
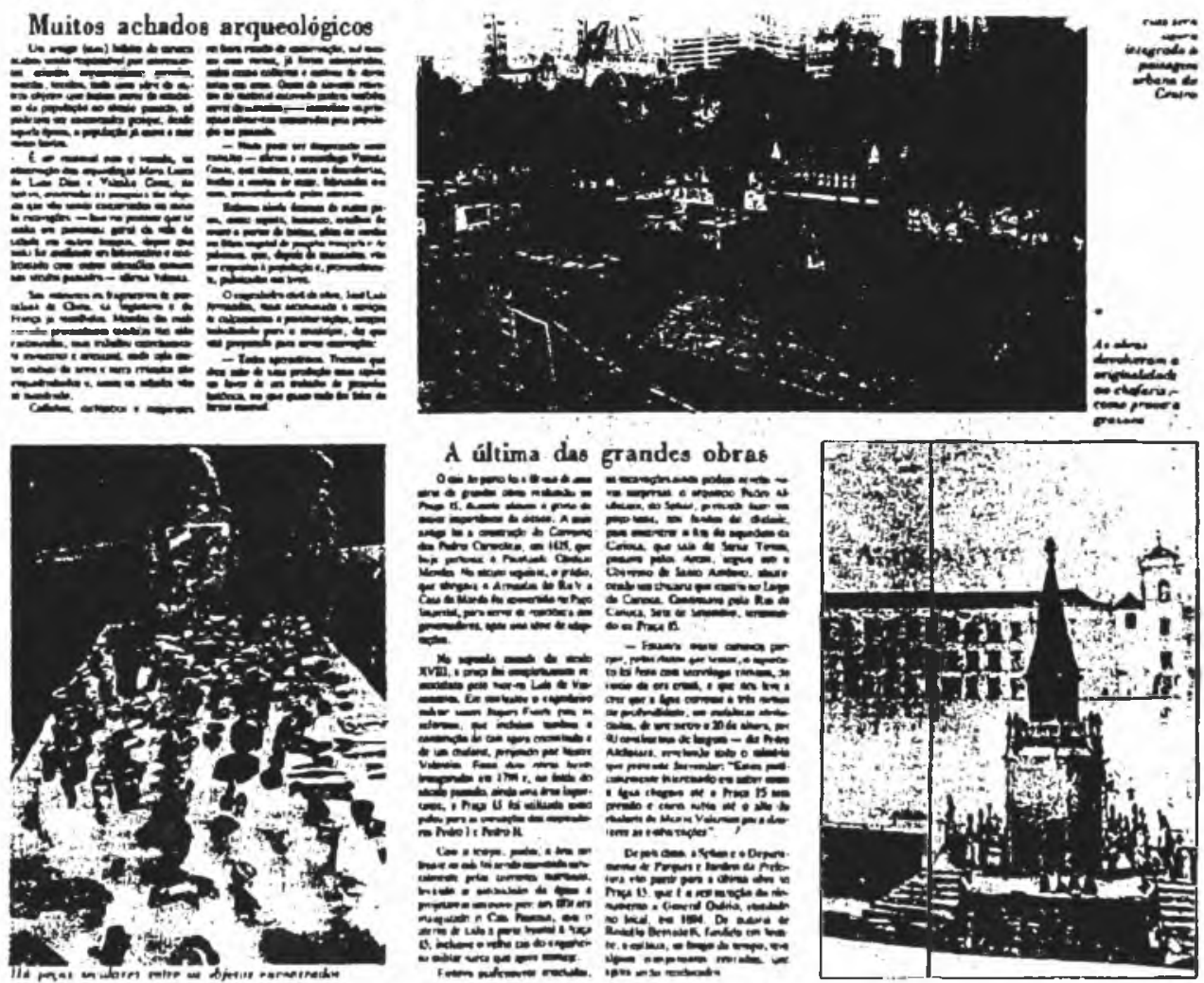

Figura 1 - $O$ velho cais da Praça 15

Fonte: Jornal do Brasil, 07/07/87 


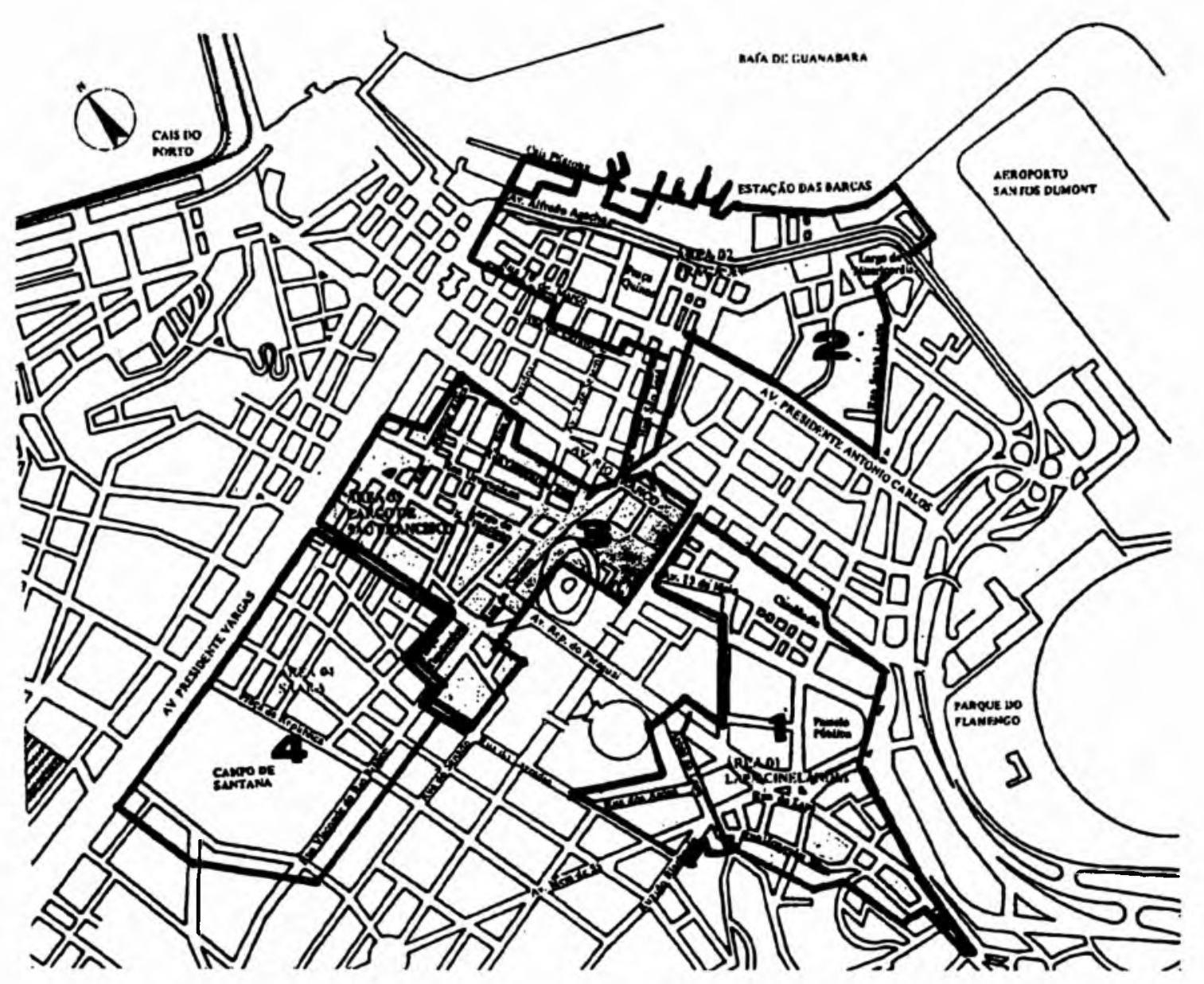

Figura 2 - Limites do Corredor Cultural. Área total: $1.294 .625 \mathrm{~m}^{2}$

Tal arcabouço teórico se nutre de fontes oriundas de campos disciplinares diversos - desde a Semiótica até a Psicologia - e tende a fornecer subsídios para a leitura do patrimônio ambiental urbano em geral.

Neste sentido, a adoção de algumas linhas de raciocínio provenientes da museologia, particularmente aquelas que incorporam a teoria da comunicação à reconceituação do espaço museológico tradicional, se apresentam como convenientes para serem aplicadas na interpretação da paisagem urbana histórica como cenário.

Foi precisamente a complexidade desta condição - decorrente do diversificado conjunto de cenários verificados na cidade que nos conduziu a aprofundarmos o estudo de diferentes interpretações da dialética da formação e/ou construção do conhecimento em geral, e da mecânica perceptiva, em particular.

Assim, inicialmente, são formuladas algumas considerações teóricas sobre a questão da legibilidade da paisagem urbana e os conseqüentes mecanismos de retenção de imagens e/ou memória (Psicologia, Semiologia, Gestalt, etc.), e ou- 
tras sobre a forma de evidenciar e/ou exibir as "peças históricas" (quase sempre marcos físicos notáveis permanentes ou não) de caráter urbano, à luz de renovadas concepções museológicas.

Na segunda parte deste artigo, já nos remetendo ao estudo do caso (a obra da praça XV de Novembro), são abordados, de forma sintética, o histórico da situação, as questões colocadas pela localização na ocasião (1987/1988), o rebatimento do arcabouço teórico inicial nas decisões do projeto e a realidade, no contexto do uso e do estado atual, da proposta efetivamente concretizada, de autoria do SPHAN.

Pretendemos, assim, assinalar as problemáticas envolvidas num projeto de intervenção na paisagem urbana, como no caso assinalado, e, ao mesmo tempo, sugerir possíveis caminhos e margens de ação ${ }^{4}$

\section{LEGIBILIDADE E MEMÓRIA NA PAISAGEM URBANA}

Uma simples e desanimadora constatação surgiu preliminarmente pouco depois de iniciados os primeiros estudos e discussões sobre este projeto: a existência de um generalizado grau de desconhecimento por parte dos habitantes da cidade, do papel significativo que muitos dos monumentos ou trechos de casarios, ainda existentes no centro do Rio de Janeiro, representam do ponto de vista da sua história.

Por extensão, poderíamos concluir - sem muita margem de erro - que a própria história da cidade, inclusive a mais recente, era uma "página escura" no imaginário popular.

Mais curioso ainda é observar que este desconhecimento não é atribuição exclusiva do segmento "leigo" do universo seus habitantes, não sendo raro verificar sua presença em círculos eruditos e/ou universitários ou até na própria imprensa.

A constatação de tal situação que oscila desde o nível da divergência de opiniões ao simples desconhecimento do assunto atinge, portanto, proporçōes surpreendentes, observadas tanto em certos juízos de valor, formadores de correntes de opinião, como nos próprios responsáveis pelas decisões projetuais na gestão pública.

Esta última situação agrava-se mais quando tais decisões convergem na "indexação" do que é "importante" e o que é "supérfluo", em termos de memória urbana, aspectos estes definitórios de políticas de tombamento e, portanto, de critérios específicos de uso do solo e de valorização da terra. 
A aceitação indiscutida do Projeto do Corredor Cultural constitui-se um bom exemplo do que dizíamos.

Como seus próprios autores afirmam, a proposta do Projeto do Corredor Cultural consiste, fundamentalmente, no ... "resgate de referências sociais, culturais e arquitetônicas"... considerado este como um ... "ponto de partida de um processo de renovação que respeite a memória da cidade"

Porém, tal assertiva, de validade quase que inquestionável, acaba se contradizendo, posteriormente, no trecho do manual, onde tentam explicar os critérios de divisão do centro do Rio de Janeiro em quatro grandes áreas.

De fato, alegando desde motivos "lógicos e operacionais", até de "conveniências de trabalho" para justificar a adoção de tais divisões, que convergem na adoção de parâmetros para leitura do espaço nem sempre facilmente percebidos pelo leitor leigo, segundo seus autores afirmam, as hipóteses de trabalho utilizadas para balizar tais escolhas, assim como o marco metodológico adotado, transformam-se em charadas de dificílima elucidação até para o leitor erudito.

Assim, segundo este trabalho, a "criteriosa" divisão surge, basicamente, das fontes representadas pelos "conhecimentos prévios e vivências dos pesquisadores", através do trabalho de campo, balizado pela observação das "características predominantes" verificadas para determinar a "identidade" de cada uma delas.

Nenhum dado aparente, à simples vista, é encontrado no projeto que permita ao observador mais curioso entender por que ficam de fora desta qualificação ponderada de áreas de interesse histórico, a praça Mauá, o morro de São Bento, a área da antiga Esplanada do Castelo (ao leste da rua Santa Luzia) ou o perímetro do antigo morro de Santo Antônio.

Independente dos méritos evidentes de uma iniciativa de preservação histórica tal como o projeto do Corredor Cultural se propõe, é evidente que uma revisão ponderada das hipóteses de seleção deve, sem dúvida, ser formulada dada a impossibilidade de se proceder a um processo de "renovação que respeite a memória da cidade", sem termos claramente quais os parâmetros em que esta se define.

Os mais de quatro séculos de história do Rio de Janeiro, particularmente aqueles em que desempenhou a função de capital, refletiram-se numa evolução e numa configuração espacial urbana característica e extremamente dinâmicas, em grande parte pontuada por marcos edificados e não edificados de diversa índole, por um lado, e pela relação do conjunto com a natureza e sua conformação geográfica, por outro.

Este animado contraponto entre o espaço construído, espaços vazios e espaços naturais (mata urbana e mar/litoral/praias) somado à lógica ebulição de um 
centro de decisão nevrálgico - quando Distrito Federal conferiram à paisagem urbana carioca, em geral, e à área do centro, em particular, uma riqueza de situações nem sempre corretamente lidas ou interpretadas.

Por outro lado, como afirma Kevin Lynch ${ }^{5}$, a cidade (...) "não é somente um objeto percebido - e talvez fruído por milhões de pessoas de classes e características acentuadamente diferentes, senão, também, o produto de agentes diversos que constantemente alteram sua estrutura, porque têm motivos para isso"...

A permanente e natural mutabilidade da cidade adquiriu um grau de aceleração de tal ordem que atinge a própria definição - ou indefinição do imaginário coletivo quanto a sua morfologia significativa.

Esta mutabilidade se acentua, no caso do Rio de Janeiro, em consequiência da dimensão nacional de numerosos acontecimentos políticos-econômicos-culturais na sua história, de investimentos de vulto e de experiências-pilotos no campo do urbanismo, que não poucas vezes assinalaram uma posição de vanguarda de efetiva concretização.

Soma-se a isso, ainda, o generalizado grau de urbanização das cidades brasileiras, e a luta constante do homem com o meio natural, obstáculo permanente da expansão urbana mais organizada (lagoas, mares, montanhas, mangues, etc.), pautada, simplesmente, por bem mais de um século, pelas questões tecnológicas nela envolvidas e pelas pressões organizadas dos eventuais grupos dominantes.

O que acontece, de fato, é uma permanente alteração, superposição e, ainda, aparecimento ou substituição de uma tal ordem de variáveis na configuração do cenário urbano, que prejudicam seriamente a clara percepção de uma qualidade visual-espacial específica, que o define enquanto categoria de análise: o grau de "legibilidade" da paisagem da cidade.

$O$ interesse no seu estudo a legibilidade reside fundamentalmente em entender e demonstrar a mecânica do processo. e qual a sua relevância na recomposição e na melhoria da qualidade de vida de nossas cidades.

O vínculo estratégico, representado pela imagem ambiental, no processo geral de orientação e identificação do habitat, enquanto representação mental generalizada do mundo exterior que constrói o indivíduo, representa o elemento mais concreto na formalização do imaginário coletivo, produto, em partes iguais, de lembranças antigas e sensações recentes.

A imagem ambiental, assim produzida, age ao mesmo tempo como um mecanismo, por parte do indivíduo, para interpretação, e como direcionamento da ação ${ }^{6}$. 
Porém, além da segurança e do realce da profundidade e da intensidade potencial da experiência humana, obtidos a partir da legibilidade visual do espaço urbano, é importante frisar a relevância do exercício e da alimentação da memória, como processo de fixação de experiência ou acontecimentos passados ou informações recebidas - significativamente expressivos e a restituição dos mesmos, num processo dialético, representando num dos seus aspectos notáveis, o próprio exercício da cidadania ${ }^{7}$

Assim, transforma-se este processo num verdadeiro ato direcionador da narrativa visual urbana, através de um sentimento afetivo de segurança e participação, obtido pela imagem ambiental que denota os fatos relevantes da história da formação do corpo social nas diferentes escalas.

Esta verbalização "perceptivo-visual" da paisagem urbana legitimaria, por assim dizer, a relevância do exercício da memória na produção dos espaços da cidade, construídos e não construídos.

Porém, a diversidade de acesso à informação, decorrente do heterogêneo universo dos habitantes da cidade, constitui dificuldade séria na mecânicả de recomposição da memória.

Trata-se, portanto, de se proceder à implementação de um verdadeiro processo de massa de educação ambiental, que privilegie o visual, objetivando a socialização da memória erudita.

A forma, por nós proposta, de incorporar tal processo ao cotidiano da cidade é através de uma interpretação de cunho museológico da paisagem urbana de valor histórico, abrangendo nesta categoria todos aqueles espaços construídos e não construídos, internos e externos, significativos ou atualmente não significativos, porém que contenham marcos de relevância para a recomposição da memória da cidade.

Outrossim, coerente com o exposto acima, tal abordagem deverá privilegiar muito mais, em termos museológicos, os seus aspectos comunicacionais, entendendo como tais aqueles que promovem a participação do usuário, do que os informacionais, que envolvem a simples transmissão estereotipada de conteúdos, freqüentemente contextualizados numa estrutura física que inibe tal participação.

Em síntese, a problemática colocada neste artigo, portanto, refere-se à questão dos mecanismos de construção e exercício da memória coletiva e/ou social, e as formas da sua realimentação e/ou enriquecimento no campo dos estudos da paisagem através de uma abordagem museológica, como forma de elevar o nível de consciência participativa nas decisões sobre a produção e a apropriação do espaço urbano pelos indivíduos que o usufruem. 
Consideramos que este enfoque sobre a relação "memória-paisagem" poderá abrir novos caminhos, conduzindo colocações mais consequientes quanto à incorporação das noções de história e cultura ao processo de desenho e à participação do usuário no projeto da cidade, do que levianas posturas "neo-vanguardistas" estetizantes ou acadêmicas, que banalizam em última análise, o próprio exercício da cidadania por parte dos seus habitantes.

\section{A NOÇĀO DE MEMÓRIA}

Dada a importância por nós atribuída à questão da memória, consideramos ser de utilidade formular algumas observaçōes sobre certas definiçōes correntemente atribuídas ao termo, muitas vezes esquecidas e/ou desconhecidas.

O Pequeno Dicionário da Língua Brasileira diz, no verbete "memória"8: (...) "Memória s.f./faculdade de reter idéias adquiridas anteriormente; lembrança, reminiscência, celebridade, monumento comemorativo, relação, apontamento para lembrança..." Ao que acrescentaríamos os termos "História" e, sem quaisquer dúvidas, "Cultura"

De uma forma ou outra, os agentes principais deste processo são indivíduos ou conjuntos de indivíduos e, portanto, não é supérfluo observarmos a abordagem da psicologia freudiana tradicional em relação à referida noção.

O dicionário de psicologia Larousse ${ }^{9}$ diz no verbete "Memória" (...) "persistência do passado, os seres humanos dão imensa importância à memória. E que sem ela a vida seria impossível. O costume, o hábito, a aprendizagem ou a educação repousam sobre "ela"... (p. 212) ..."A memória fixa experiências vividas passadas, as informações recebidas, e as restitui..."

Alguns psicólogos, preocupados em dar uma significação precisa a este conceito, consideram como já mencionamos - que a memória se deve traduzir por um ato: a condução da narrativa (a verbalização autêntica de certo modo, a existência da memória) ${ }^{10}$.

Ao afirmarmos que a memória restitui o que foi fixado, estamos nos referindo a aquilo (vivência, sensação ou fato) que foi percebido como essencial.

Ou seja, o exercício da memória é um ato ideológico, no sentido dado por Michel Foucault $^{11}$, isto é, um recorte no continuum da realidade, prévio à fixação ${ }^{12}$.

Assim, a fixação das recordações está relacionada ao mesmo tempo - ao peso e ao material a ser retido. A compreensão (legibilidade) dos elementos, sua integração no mosaico das lembranças adquiridas ou construídas (escolhidas) e a repetição (faixas de redundância) favorecem a retenção. 
Embora a recordação que se evoca ou restitui é sempre "falsificada", pois corresponde a uma reconstrução (seleção/recorte) da inteligência (o consciente).

A psicologia atribui esta condição à memória, na medida que considera que o processo que ela implica não constitui um automatismo cerebral, mas, fundamentalmente, um ato do psiquismo, a expressão de todo o indivíduo ${ }^{13}$.

\section{MEMÓRIA AMBIENTAL E SISTEMAS DE REPRESENTAÇĀO}

Nas questões anteriormente colocadas, duas categorias estão marcadamente embutidas, e não tão claramente definidas, que decorrem naturalmente da questão ligada ao processo de seleção da inteligência (consciente), tanto na fixação como na recuperação das recordações: a distinção entre as noçōes de "Real" e "Imaginário"

Quando estas colocaçōes sãó rebatidas no estudo da legibilidade, fica evidente que dependendo da concepção da organização do espaço físico, por cada estrutura social, em cada momento histórico, as representações coletivas do meio ambiente apresentam conotações diversas.

No entanto, estes "sistemas de representação" conformam um todo tão fortemente enraizado no cotidiano do homem - independente da configuração espacial do seu meio ambiente que este o sente como algo "natural", como parte componente dele mesmo ${ }^{14}$

Existiria, assim, um curioso processo de leitura do espaço urbano, caracterizado pela forma "natural" como se incorporam as imagens da paisagem (construída ou não) da cidade à percepção dos seus habitantes.

Esta aparente naturalidade, não poucas vezes é comparada ao enfoque que habitualmente é dado à questão da linguagem que, como outras habilidades específicas adquiridas ou, ainda, objetos e pessoas, pensamentos, etc. incorpora-se de forma subliminal (popularmente chamada de "natural") ao consciente/subconsciente dos seres humanos, pela sua reiteração cotidiana.

No caso da paisagem urbana, a referida forma "natural" como se percebe sua narrativa incorpora-a visualmente ao cotidiano dos seus usuários, portanto, sem questionamentos, determinando uma relação imaginária deste com o seu habitat ${ }^{15}$.

Queremos dizer com isto que os sistemas de significação/representação acabaram adquirindo uma qualidade de "invisibilidade", decorrente da nossa convivência diária com eles.

Porém, antes do imaginário ser considerado como oposto à realidade, deve ser considerado como uma das vias para entrar em contato com ela: a relação ima- 
ginária entre o Homem e seu meio ambiente é de tal proximidade e familiaridade que se estabelece uma mimese entre ambos.

Um bom exemplo disto é a comparação entre as diferentes formas de se perceber uma paisagem nacional e internacionalmente conhecida, como é o caso da vista do morro Pão de Açúcar, no Rio de Janeiro.

São evidentes as diferenças entre as leituras da narrativa da paisagem vista por um habitante da cidade com a que convive diariamente, a caminho do trabalho (Parque do Aterro do Flamengo), do alto de um restaurante (edifício do Clube da Aeronáutica), ou como lugar de moradia (bairro da Urca) com a visão de um habitante de outra cidade, através de um cartão postal, uma fotografia ou um filme, para quem isso pode estar carregado de reminiscências.

De fato, enquanto no primeiro caso, paisagem urbana e Homem entram em relação imaginária, pela não explicitação como signo da massa construída e natural, no segundo a imagem incorporada a um meio de comunicação (o cartão postal) adquire plenamente o caráter de signo.

\section{UMA CATEGORIZAÇÃO GERAL PARA AS BIPOLARIDADES DIALÉTICAS}

Uma das conclusões mais instigantes que surgem do uso da noção de relação imaginária, quando aplicada à questão do exercício da memória - e, portanto, da fixação e da recuperação das imagens e sensações -, que por sua vez nos remete à questão da "legibilidade" do espaço urbano, é a possibilidade de termos nas mãos uma das chaves mais importantes para categorizar uma série de outras "bipolaridades dialéticas" - assim denominadas por A. Moles ${ }^{16}$ - de grande utilidade para a interpretação do espaço visual urbano e a lógica de estruturação e interpretação de sua retórica.

Porém, antes de continuarmos este raciocínio, é necessário fazer uma breve e sucinta resenha das "bipolaridades" por nós escolhidas para estudo proposto.

\section{FORMA/FIGURA E FUNDO}

No campo da percepção, esta relação verifica-se a partir da forma dos objetos, e vice-versa, ou seja, também percebemos a forma por causa da relação entre os objetos.

Isto significa que a forma depende do objeto observado e também do observador, e na medida que nos indaguemos como percebemos a forma, encontraremos na sua resposta a base para responder, por sua vez, a questão fundamental: como criamos relaçōes? Através do contraste. 

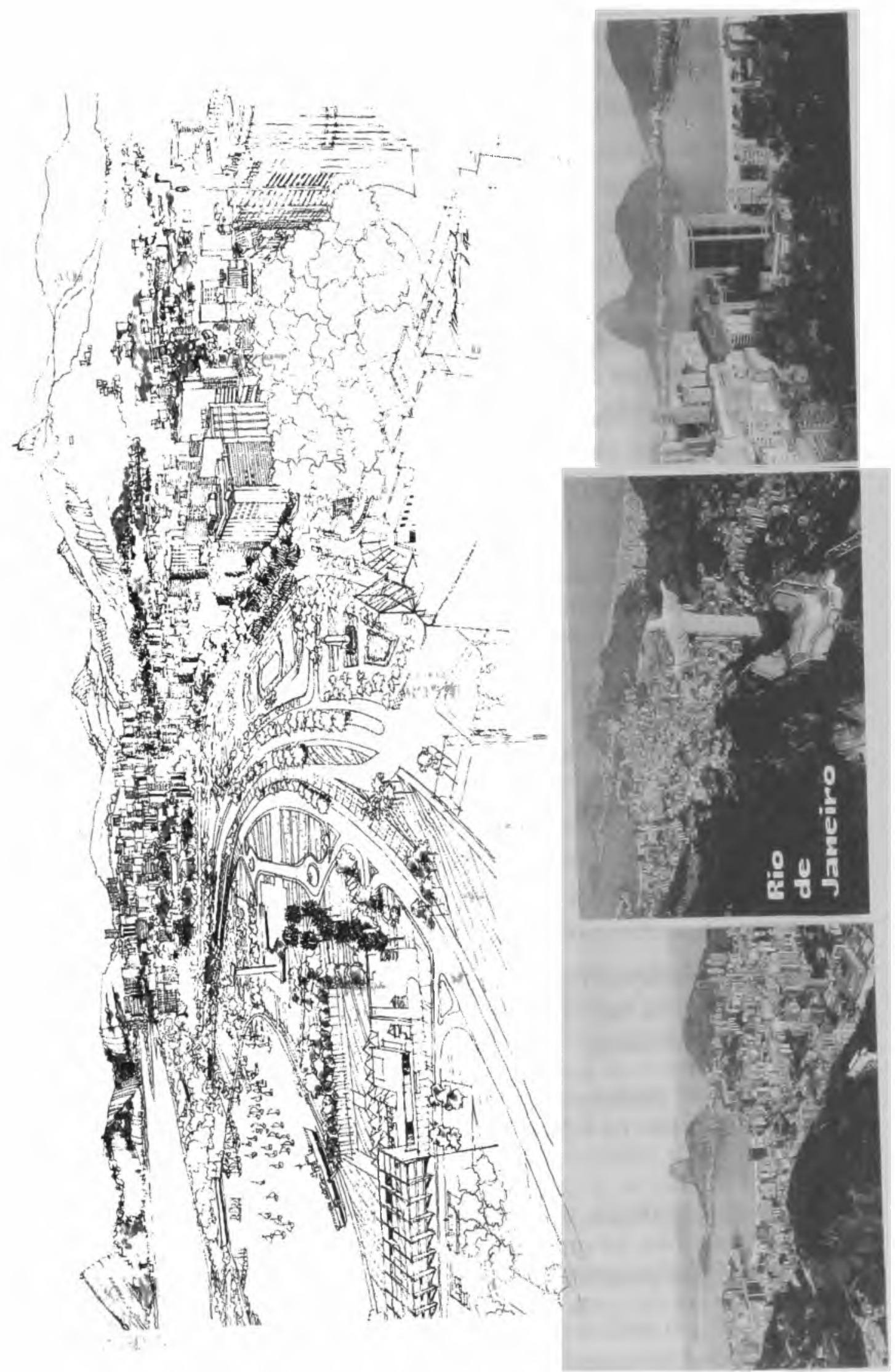
Com isto queremos afirmar que a percepção da forma é o resultado das diferenças no campo visual, ou, em outros termos, quando percebemos a forma significa que devem existir diferenças no campo, e quando há diferenças, há contraste.

Este constitui um dos fundamentos básicos da Psicologia da Gestalt, isto é, o da oposição figura-fundo: a figura, portanto, não se define completamente senão por sua oposição ao fundo. Destaca-se por sua organização sobre um fundo desorganizado $^{17}$

Somos, desta maneira, levados a centralizar nossa atenção no "fundo amorfo" do qual deve emergir o sinal significativo, como a ação teatral se apresenta sobre um pano de fundo, que é caracterizado pelo fato de existir mas não nos interessar.

$E$ esse desinteresse que. define o fundo sobre o qual devem destacar-se os fenômenos interessantes (formalfigura).

Esta relação interesse/desinteresse é de fundamental importância para se entender os processos de legibilidade do meio ambiente, assim como os mecanismos de fixação/retenção/recuperação dos elementos que compõem a memória.

Assim, o estudo e o controle dos mecanismos indutivos da relação "interessedesinteresse" terão a sua relevância assegurada na percepção visual do espaço urbano, já que permitem aprimorar os meios de narrativa perceptual da cidade.

\section{A NATUREZA DA RELAÇĀO FIGURA-FUNDO À LUZ DA RELAÇĀO SINAL-RUÍDO}

A mensagem engloba, em seu contexto conceitual, um conjunto de aspectos que não interessam ao receptor.

Chamadas perturbações ou erros caracterizam, na Teoria da Informação, o conceito de "ruído", ou seja, todo aquele sinal indesejável na transmissão de uma mensagem por um canal.

A distinção entre ambos (sinal e ruído) deve se basear no grau de intencionalidade da fonte, e não na relação ordem/desordem, como inicialmente parece sugerir $^{18}$.

Entretanto, por analogia, no caso da mensagem do meio ambiente para 0 indivíduo, o transmissor, na qualidade de indivíduo, não existe, subsistindo só o receptor; daí surge a possibilidade de se poder generalizar a teoria em outros termos.

Assim, o ruído, na análise do ambiente, é um sinal que não se quer receber, ou seja, que o indivíduo-receptor se esforça para eliminar. 
Como complemento indispensável da relação ruído-sinal, como expressão no campo da Teoria da Informação da relação fundo-figura/forma, é necessário esclarecer nossa interpretação da noção de redundância ou faixas de redundância.

Em linhas gerais a noção de redundância é uma forma de superação dentro do código do ruído, que em princípio pode ser entendida como repetição do sinal, para evitar ambigüidade na sua interpretação.

Visa, no geral, conferir um certo grau de segurança à comunicação, e ao aumentar o nível de sua aplicação, aumenta sua previsibilidade, introduzindo no sistema uma certa capacidade de absorção de ruído, diminuindo a sua possibilidade de erro, aumentando a entropia.

Em síntese, a uma menor taxa de ruído, teremos possibilidade de obter uma boa informação, e precisaremos de menos redundância e entropia (menor previsibilidade), sendo o oposto também verdadeiro.

A assimilação destas categorias comunicacionais às utilizadas por M. McLuhan, ficam assim evidentes: um meio "quente" é um meio de alta definição, ou seja, um meio rico em dados informacionais para o receptor e que exigem, portanto, uma menor participação dele, já um meio "frio" seria relativamente pobre em informação, e em consequiência estimularia a audiência a uma maior participação.

Para poder fechar uma conciliação ou compatibilização de ambas as categorias, é necessário acrescentar as esclarecedoras observações quanto aos "tipos de ruídos' feitas por Moles.

De fato, ao contrário de Eco e Pignatari, Moles estabelece uma "tipologia" de ruídos, ao falar indiretamente em ruídos "desejáveis" e "não-desejáveis", ou em outros termos, "intencionais" e "não-intencionais"

Quando o autor se utiliza do inteligente exemplo da transmissão radiofônica de um concerto ao vivo, na qual são omitidos os acordes iniciais para afinação dos instrumentos, por serem ruídos "indesejáveis" e, após o concerto, são transmitidos os aplausos do público presente, como encerramento do evento, por serem ruídos "desejáveis", a classificação antes mencionada se clarifica.

Se nenhuma diferença morfológica existe entre sinal e ruído, a tal ponto que ambos podem ser confundidos, qual seria sua distinção? A noção de redundância poderá servir como uma poderosa ferramenta para esta compreensão.

Se, por definição, o ruído é uma interferência na comunicação do sinal, e ambos têm a mesma natureza, o ruído é um sinal que não se quer transmitir, ou é um sinal de outra ordem. 
Existirão "sinais-ruídos". que depois de um tempo suficientemente longo terão a possibilidade de se reencontrarem em todas as suas amplitudes possíveis e a... "superposição do conjunto desses espectros contínuos dará lugar a um espectro contínuo permanente, em que todas as "freqüências" têm a mesma probabilidade de ocorrência"... 19

Antes da noção de redundância aplicada ao sinal, Moles nos fala aqui da "redundância do ruído", como forma de incorporar-se ao sinal, como "pano de fundo", é o que denomina como "ruído branco", protótipo do ruído ideal perfeito.

Definindo assim o conceito de "ruído branco" facilmente assimilável por analogia, à noção de fundo, uma última observação de importância consideramos útil fazer: em que medida o sinal pode se transformar em "ruído branco" pelo excesso do nível de redundância?

De fato, se a redundância funciona como amortecedor do sinal-ruído indesejado, ao aumentar a freqüência no tempo do sinal, em que medida ele não pode se transformar num ruído branco, pela sua alta previsibilidade, ou, nos termos de McLuhan, pelo seu "aquecimento"?

A resposta a esta questão adquire relevância nos estudos de legibilidade e, portanto, de identificação da paisagem urbana como decorrência da numerosa multiplicação e justaposição de sistemas de elementos fixos e móveis que se incorporam, como suporte e configuração, à retórica espacial da cidade.

\section{MUSEOLOGIA E PAISAGEM URBANA}

Voltando à proposição inicial da abordagem museológica do exercício da memória no campo dos estudos da paisagem julgamos ser necessária a formulação de alguns esclarecimentos sumários sobre o assunto.

Estas ressalvas são pertinentes, principalmente, porque as clássicas conotações que tal abordagem possa suscitar, podem conduzir a erros de interpretação e/ou avaliação.

No campo específico dos museus, estes tiveram, tradicionalmente durante séculos, o verdadeiro papel de testemunho dos "mortos ilustres" das antigas civilizações, não sendo em vão que os primeiros grandes museus da humanidade tenham sido indiscutivelmente os túmulos.

Segundo esta noção de memória, surgida do conceito de materialidade, os objetos, além de sobreviverem aos seus donos, teriam um discurso mais "confiável" que o dos homens. 
As afirmações anteriores resumem boa parte da história da museologia, pois esta surge como manifestação física da obcecada luta pela permanência e/ou "sobrevivência" dos indivíduos e, por extensão, dos povos.

Esta concepção tradicional do museu que de certa forma se remonta aos sécs. XVII/XVIII - ainda permanece, em parte, com vocação de sobrevida, porém com uma tendência clara para uma crescente elitização e marginalização do consumo massivo.

É precisamente a preocupação de certos setores mais esclarecidos deste campo disciplinar, que direciona nos últimos anos, uma reconceituação do espaço museológico, que transcende a envolvente física do museu, como única forma de sobrevivência dessa instituição, tradicionalmente consagrada ao passado.

Ou seja, os princípios gerais que norteiam este novo pensamento museológico se expressam, no geral, numa sensível mudança, tanto na sua filosofia, como nas consequientes mudanças de comportamento dos próprios gerenciadores da instituição "museu" sintetizada na busca de incorporá-la de forma mais ativa ao corpo social.

Utópicas ou não, estas tentativas têm o valor de propor uma inversão de expectativas em relação à interpretação elitista da estrutura museológica, ao promover sua transformaçāo em importante agente da formaçāo de um senso crítico coletivo.

A conveniência destas afirmações, em nosso caso, reside fundamentalmente, na possibilidade delas serem rebatidas nas questōes da legibilidade do espaço, particularmente no que se refere a mencionada socialização da memória urbana erudita.

De fato, o crescimento e a permanente mutabilidade da paisagem urbana e, junto, os sítios históricos nela contidos, nos permitem verificar um distanciamento cada vez maior do imaginário coletivo da historicidade da cidade e, conseqüentemente, da sua própria identidade.

Assim. trata-se de estimular, através desta abordagem. a incorporação da leitura do histórico à própria narrativa da paisagem, concomitante com a conceituação de museus "frios/participativos"

A distinção entre esta conceituação e uma função "quente/informativa (segundo as categorias de $\mathbf{M}$. McLuhan ${ }^{20}$ reside na oposição entre o grau de participação que a primeira promove, e a simples transmissão de conteúdos pré-elaborados que a outra representa, numa estrutura física que inibe tal participação.

No campo específico da museologia, a concepção tradicional desta estrutura é essencialmente informacional e não comunicacional, o que tornaria necessária a criação de novas linguagens para alterar tal quadro. 
O paradoxo inicial de que um bom espaço museológico deveria oferecer "pouca" informação, é só aparente: a comunicação somente se estabelece quando uma mensagem pode ser complementada pelo seu interlocutor.

Logo, não é somente a falta de informação que caracterizaria os museus "frios" e sim a possibilidade de transformá-los em estrutura comunicacional, condição básica do processo de exercício da memória e da condição "real" em termos lacanianos.

Assim, o rebatimento desta nova concepção museológica nos estudos da paisagem urbana ruas, calçadas, praças, parques, avenidas - evidencia vantagens óbvias no que concerne à proposta de incorporação socializada da historicidade mencionada, ao contribuir para o estabelecimento de diretrizes objetivas para a narrativa visual proposta pelos elementos espaciais que a compõem.

Concluindo, a idéia do "museu de rua" ou "museu-rua" embora não inédita, adquire um contorno revolucionário porque contribuirá para a solidificação na noção de "raízes" e, portanto, atingirá um nível de conscientização participativa de alcances insuspeitados, através da correção de uma deficiência na retenção da memória coletiva urbana.

Por outro lado, as implicaçōes políticas de uma ação conseqüente neste sentido, embora imprevisíveis pelo seu potencial de mobilização, terão, sem dúvida efeitos altamente positivos, contribuindo, também, para a recuperação do exercício pleno da cidadania.

Entretanto, ainda, no campo da museologia, verificamos no mesmo uma tendência generalizada a interpretar a estrutura física "museu" como um continente de mensagens. Embora parcialmente válida, face a diversidade das obras contidas, esta afirmação ignora um denominador comum entre ambos, que é sua condição de signo.

Obviamente, ao formularmos esta afirmação não podemos esquecer uma clara distinção entre a condição da obra e da "estrutura/suporte": enquanto as primeiras constituem um sistema de signos, a segunda - que as acolhe - representa o signo de uma cultur $a^{21}$

O espaço museológico, de fato, sugere representações convencionalizadas no receptor (em forma bastante similar a paisagem humana) ao interpretá-lo, também, cọmo um conjunto de signos (um signo que compreende outros signos), ou seja, no seu duplo caráter de significante e significado.

Como significante, se relaciona à função institucional e aos sentidos instituídos do museu como expressão de uma época e de uma cultura e não com sua parte física. 
Como significado, o museu fora parte dos sentidos mais amplos de uma sociedade, e se configura de acordo com certos padrões culturais, e, fundamentalmente, aos seus conteúdos concretos (livros, manuscritos, pinturas, vídeos, gravuras, esculturas, etc.).

Neste sentido, cobra fundamental importância levar em conta quais os canais que contribuem estruturalmente com a ação museológica e seu sentido social.

Nos referimos, particularmente, às diversas mediações entre a peça a ser exibida e o receptor, isto é, nos termos em que se manifesta a dialética da narrativa expositiva de um objeto: a peça, o suporte e o espaço continente.

De fato, relembrando Moles, suporte e espaço estariam muito próximos da sua conceituação de "fundo amorfo" sobre o qual somos levados a centralizar nossa atenção, e do qual deverá emergir o "sinal significativo"/ a peça / da mesma forma que uma ação teatral sobre um pano de fundo ou cenário (existe, mas não nos interessa/relação imaginária).

Porém, o problema que com maior freqüência se nos apresenta, é que nem sempre os panos de fundo contêm a mesma qualidade de amorfo a que Moles se refere, enquadrando-se mais na categoria de "ruído branco"

Consideramos que o problema maior envolvido na questão do "pano de fundo" reside menos em quanto mais ou menos "amorfo" ele seja, do que no grau de ruído indesejável ou, ainda, de complementação do sinal significativo (a peça) que ele contenha.

A assimilação desta conceituação do espaço museológico à leitura e tratamento da paisagem urbana, particularmente no que se refere a sítios históricos, adquire uma utilidade operacional inestimável devido à notável semelhança.

De fato, ela nos fornece vantagem de eliminar, pelo menos em parte, aquele duplo caráter, tanto pela quantidade de informação, quanto pelo nível de redundância própria do meio urbano, se aproximando da condição do cenário.

Outrossim, aparecem suportes intermediários, já que a "peça" passa a ser um segmento do próprio espaço urbano, que pode evidenciar sua história e evolução, e, ao mesmo tempo, permitir o "recorte" da peça principal (existente) do "fundo amorfo" antes mencionado.

O centro do Rio de Janeiro, por exemplo, se apresenta como um laboratório excelente para tais experimentaçōes, na medida que apresenta uma riqueza e relevância expositiva do espaço urbano, a nível nacional, que decorre tanto de sua história como das particulares condições do meio geográfico natural onde se insere. 
A interação entre ambiente construído-evolução-ambiente natural, nos fornece uma multiplicidade de suportes referenciais, de fundamental importância para ativar os mecanismos de seleção, fixação e recuperação da memória - imaginário coletiva como tentamos evidenciar em nossos desenhos e em nossas próximas observações sobre o caso analisado.

\section{PAISAGEM E HISTÓRIA}

A praça XV de Novembro (antigo largo do Paço) talvez seja um dos segmentos urbanos do centro do Rio de Janeiro que sintetiza o maior número de elementos configuradores do espaço urbano carioca, ainda verificáveis em nossos dias.

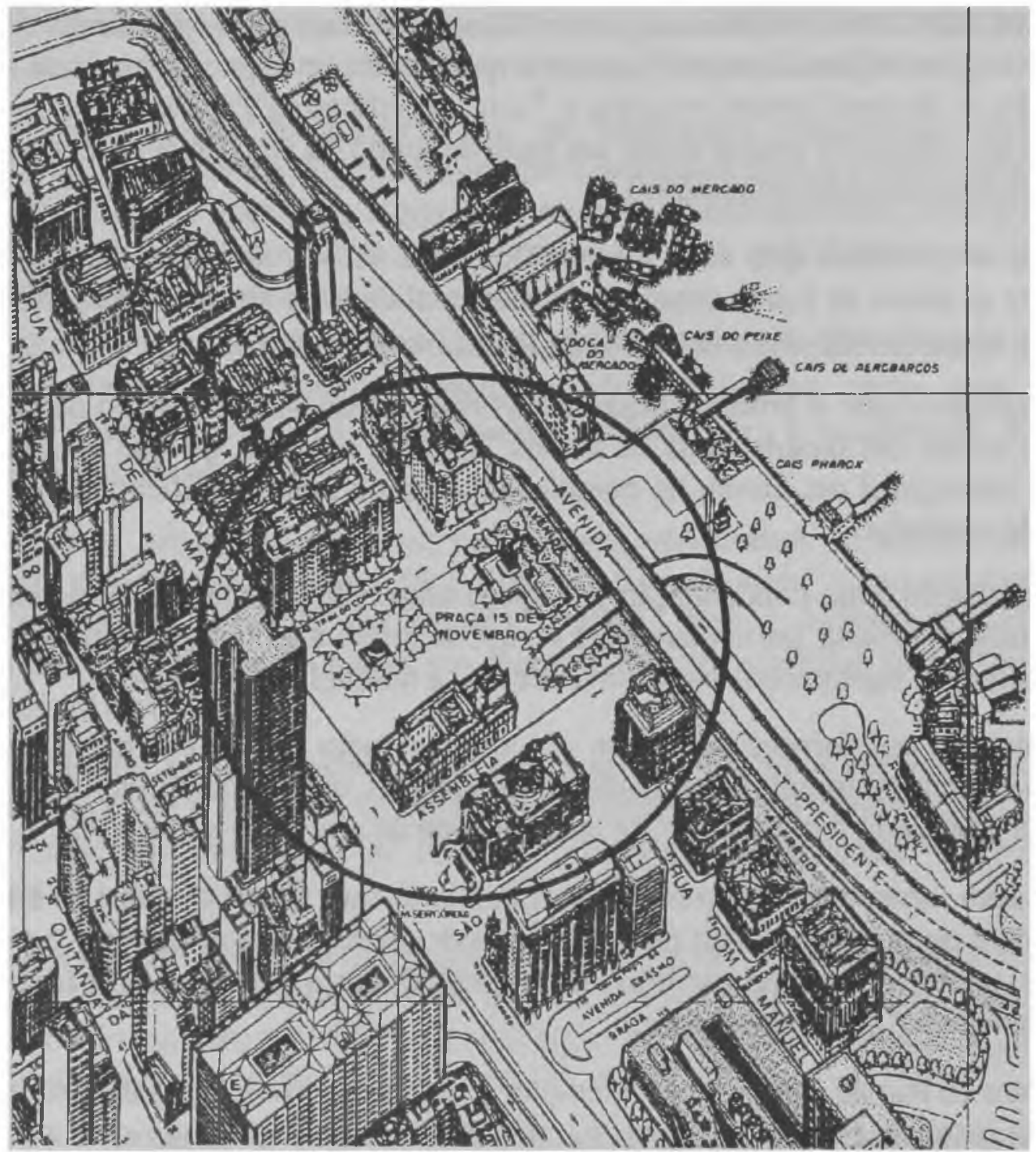

Figura 4 Vista axonométrica do centro do Rio de Janeiro, focalizando a área da praça XV de Novembro e adjacências, segundo levantamento de 1988 (des. Vitor A. Castro) 
E, sem exageros, nenhum estudo sobre a evolução urbana da cidade pode ser feito sem a clara apreensão do crescimento deste fragmento urbano, cuja leitura visual nos denota claramente os caminhos que desde o período colonial reservaram ao Rio de Janeiro uma importância única na história do país.

Por alguns séculos esse era o lugar onde - na escala nacional se concentravam os marcos do poder, além do lugar onde todos desembarcavam (a "Porta do Brasil").

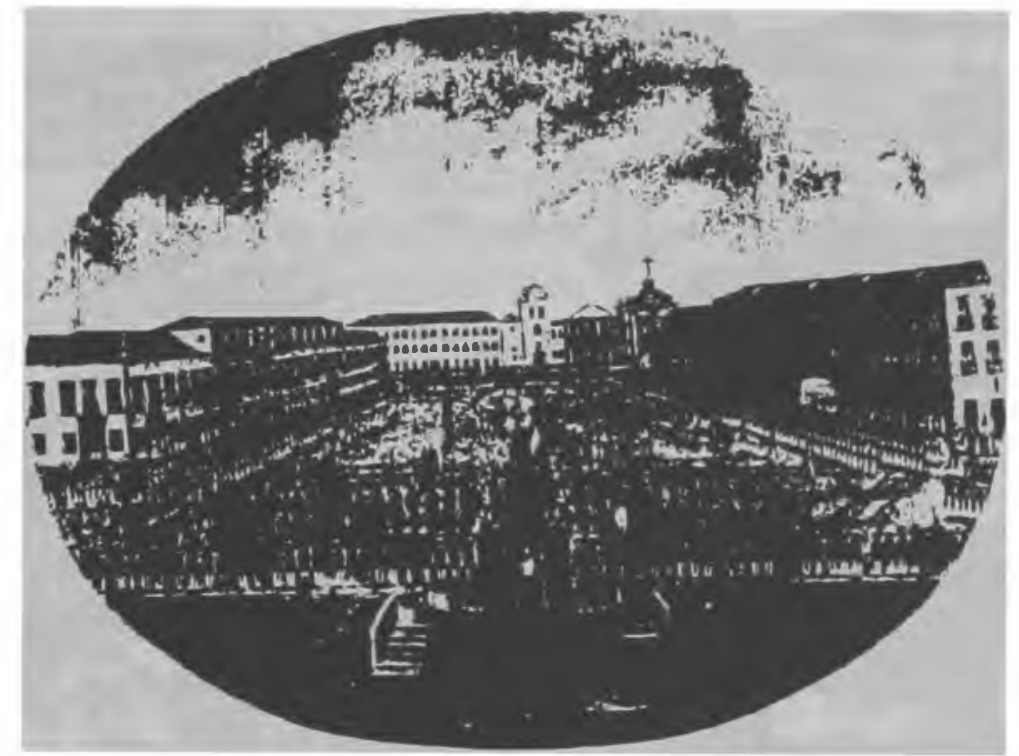

Figura 5 "Revista Militar no largo do Paço" tela de Leandro Joaquim do final do século XVIII. Em primeiro plano, o cais e o chafariz de Mestre Valentim, recém-construídos; à esquerda, o entāo Paço dos -Vice-Reis; à direita, os sobrados dos Teles de Menezes, com o Arco do Teles e, no fundo, o convento carmelita e respectiva igreja, tendo contígua a igreja da Ordem Terceira do Camo

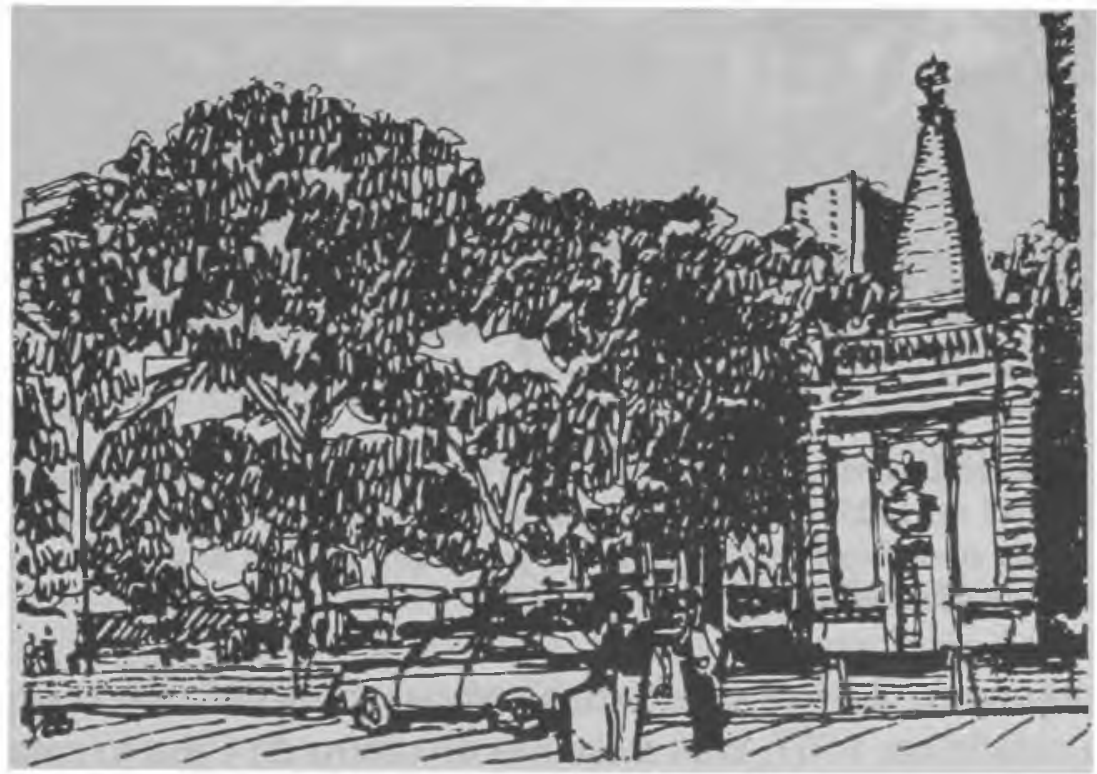

Vista do chafariz do mestre Valentim a partir da avenida Agache em 1987 (desenho do autor) 


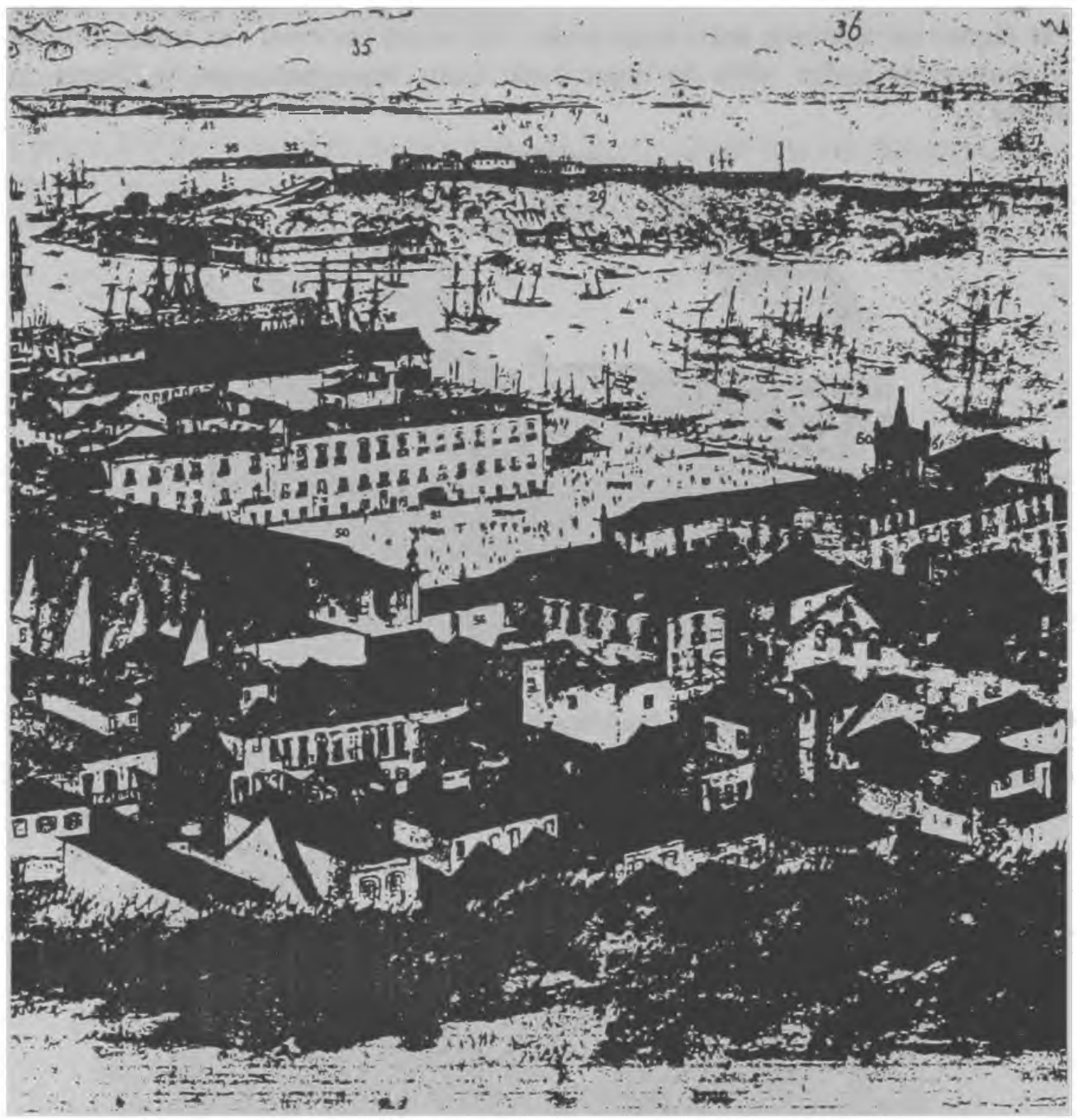

O largo do Paço e adjacências, visto do morro do Castelo segundo trecho do belíssimo panorama de $360^{\circ}$ William John Burchell em 1825. Nesta prancha tem-se por primeira vez uma visão norte-sul do Paço Real (na época ligado ao convento do Carmo por um passadiço), do largo do Carmo e o arco do Teles (Coleção Biblioteca de Johannesburg-Africa do Sul)

A história do centro do Rio de Janeiro começa propriamente com a segunda fundação da cidade em 1567, com a escolha do morro do Castelo para ocupação, 
local militarmente mais seguro pela sua posição defronte à barra, permitindo uma excelente visualização da entrada dos navios.

Porém, já em fins do séc. XVI e começo do séc. XVII, inicia-se um processo de abandono do morro do Castelo, face à ocupação e ao desenvolvimento das áreas planas adjacentes - as várzeas constituídas em geral por pântanos, alagados, lagoas e mangues.

A este respeito comenta $\mathrm{P}$. Sisson ${ }^{22}$, que apesar de requerer extensos aterros, a ocupação da várzea apresentava vantagens evidentes devido à facilidade de acesso ao litoral, condição vital para a atividade mercantil que sustentava economicamente a cidade.

Consolidado, assim, este novo movimento de ocupação, podemos afirmar que o perímetro para desenvolvimento de sua área habitável, como consequiência das dificuldades geográficas, ficava virtualmente delimitado por um retângulo, cujos vértices eram assinalados por quatro morros: o do Castelo, o de Santo Antônio (antigo Outeiro do Carmo), o de São Bento (antigo Manoel de Brito) e o da Conceição (vide planta anexa).

Estas colinas, assim como o perfil da restinga arenosa representada pela então praia da Piaçaba, balizaram e condicionaram a extensão e o traçado das primeiras ruas.

A primeira delas, a rua Direita (atual ruả Primeiro de Março) ligava, na sua emenda com a rua da Misericórdia, o morro do Castelo com o morro de São Bento, articulando-se à primeira praça formada na várzea: o terreiro da Polé, posteriormente chamado de largo do Carmo, atualmente praça XV de Novembro.

Podemos afirmar, sem exageros, que o esquema básico de desenvolvimento do núcleo urbano representado pelo atual centro do Rio de Janeiro, manteve-se sem grandes alterações até o séc. XIX, o que pode ser claramente observado nos mapas da evolução urbana da cidade ${ }^{23}$.

Em grande parte, como afirma $M$. Abreu, esta estagnação deve-se às dificuldades de acesso ao interior, tanto pela precariedade dos meios de locomoção, como pelos obstáculos físico-geográficos típicos do ecossistema local.

No entanto, o terreiro da Polé (posteriormente largo do Carmo e do Paço) manteve uma dinâmica espacial atípica se comparada com a imobilização do resto da cidade.

De fato, enquanto o processo de ocupação da várzea se desenvolvia, os marcos edificados por iniciativa governamental no morro do Castelo se deslocavam, no séc. XVII e parte do XVIII, para a planície, particularmente nas adjacências do largo do Carmo. 

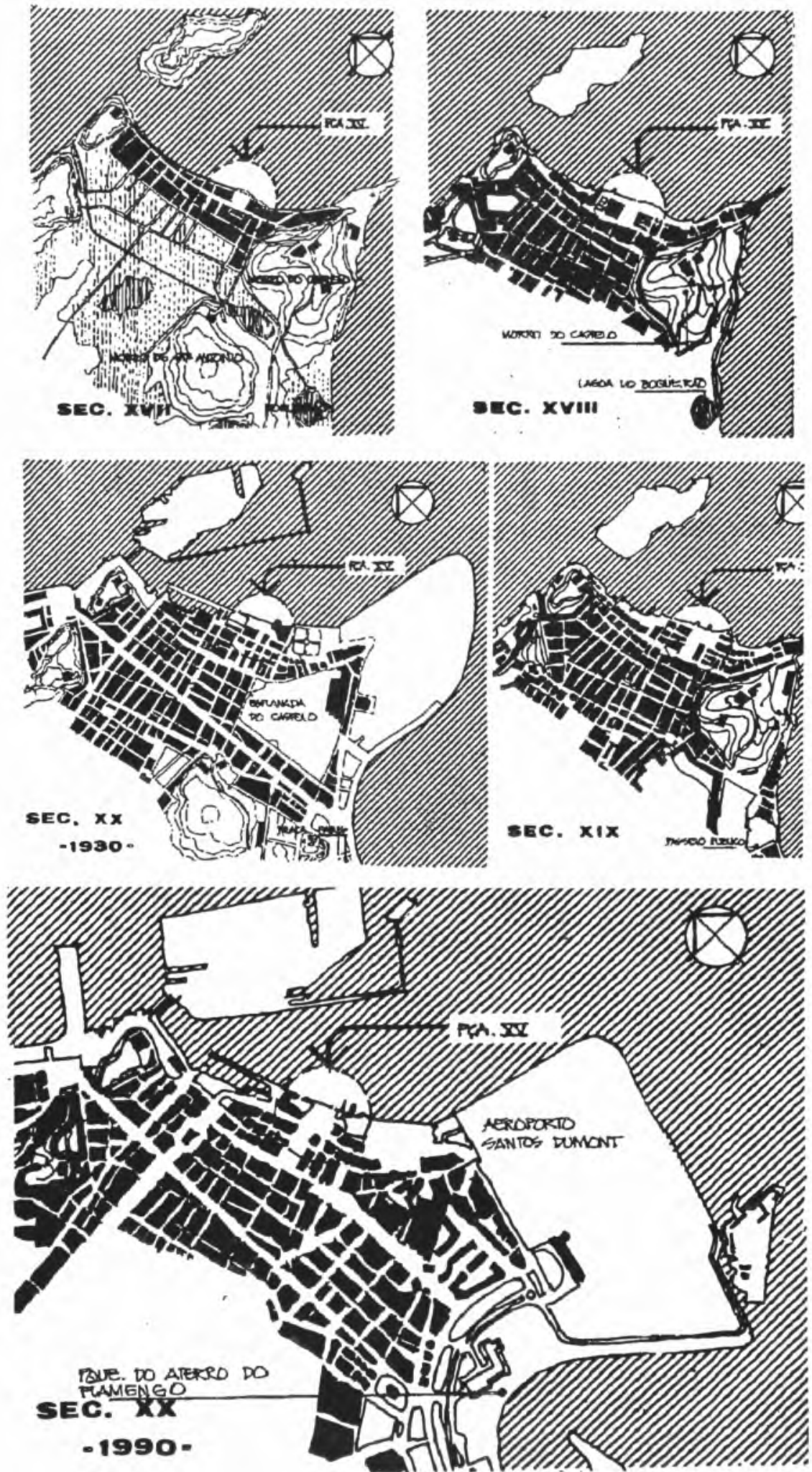

Figura 6 - Plantas da evolução urbana do centro do Rio de Janeiro, a partir do Atlas da Evoluçāo Urbana da cidade do Rio de Janeiro - Ensaio/1565-1965, de Eduardo Canabrava Barreiros/Instituto Histórico e Geográfico Brasileiro/1965 
Isto constitui um fato notável no Rio de Janeiro, visto que até o séc. XVIII as principais referências de estruturação urbana da cidade, e conseqüente configuração de espaços vazios historicamente significativos, eram os marcos religiosos ${ }^{24}$.

Portanto, o largo do Carmo representa o único exemplo de espaço vazio dentro da malha urbana que não se destinava exclusivamente à atividade sacra.
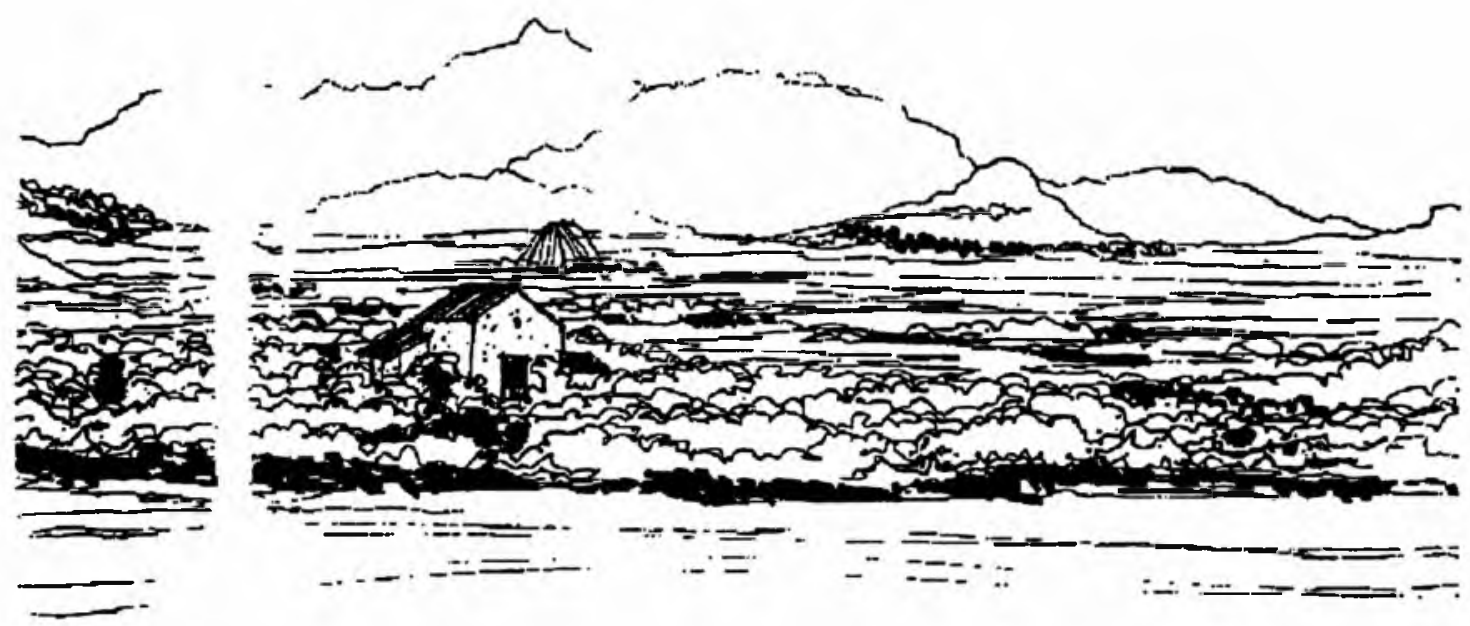

1830
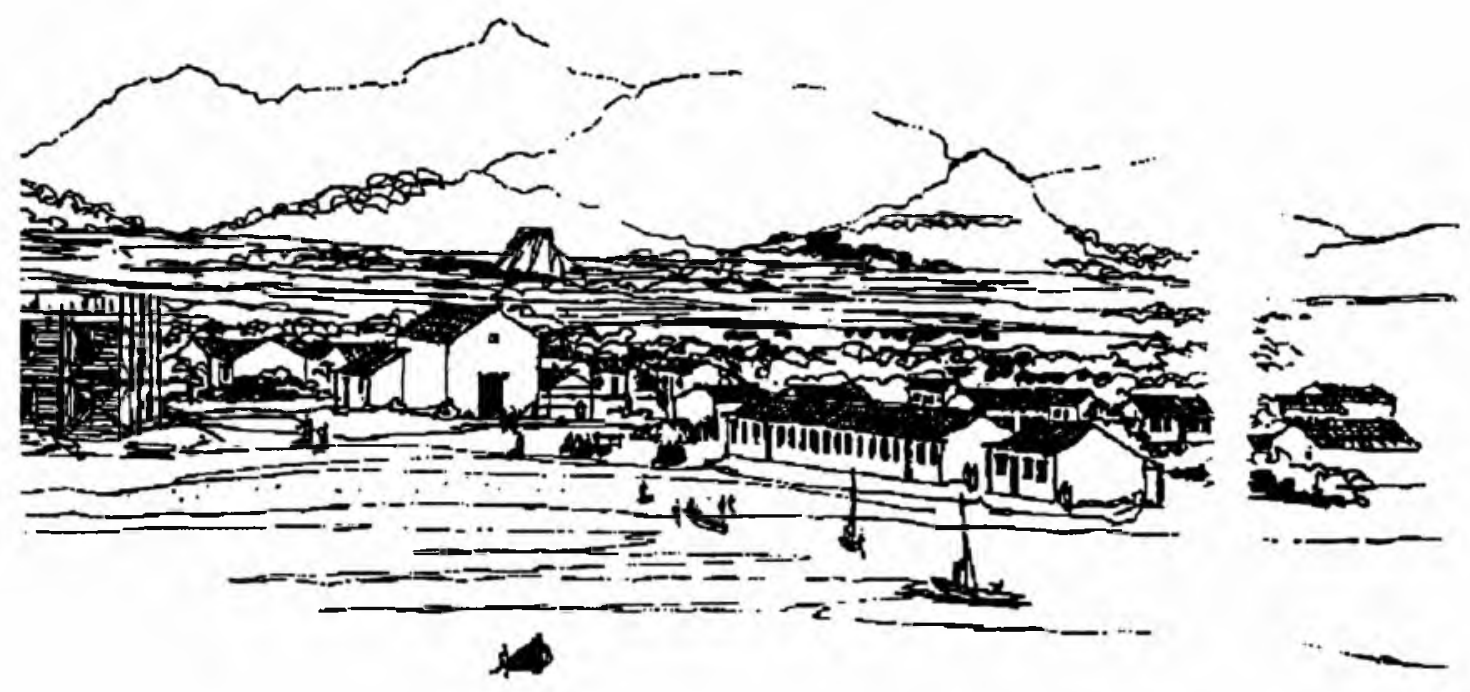

1020 

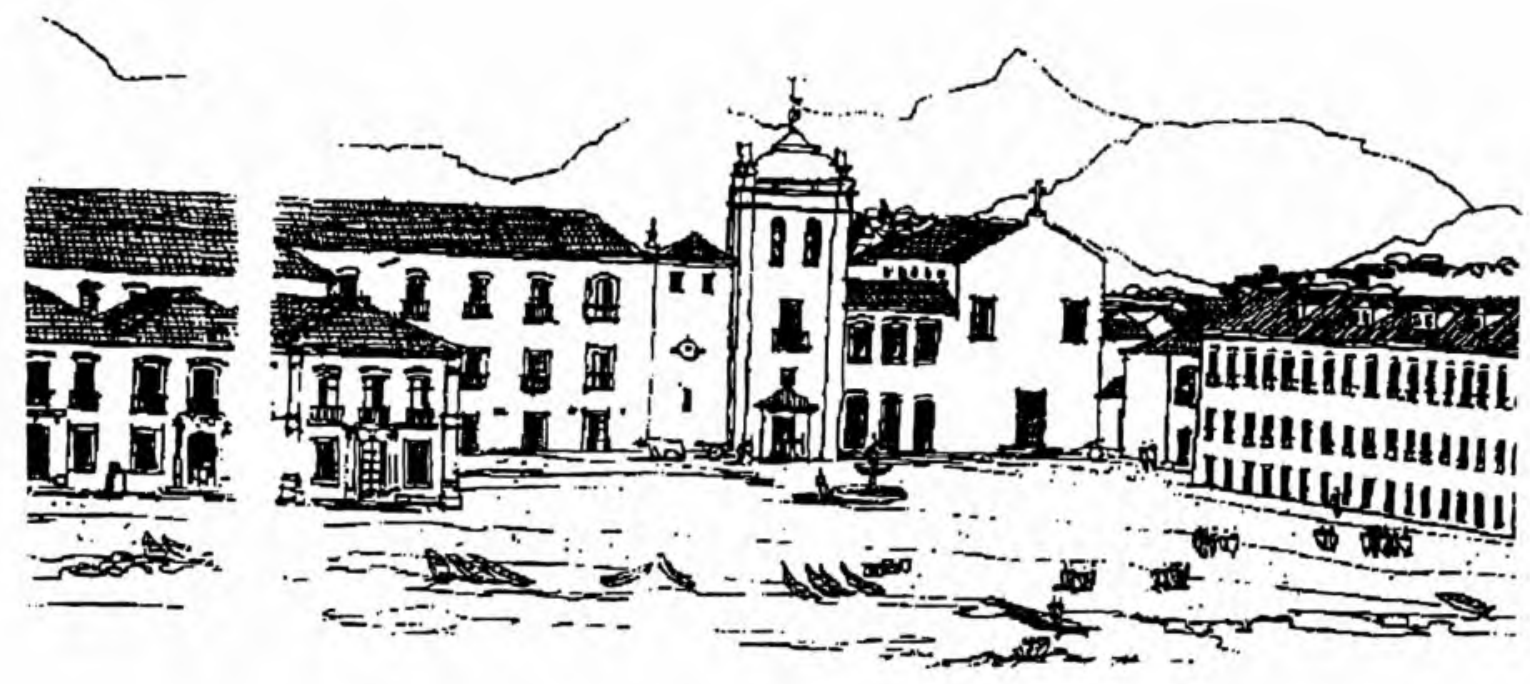

1780
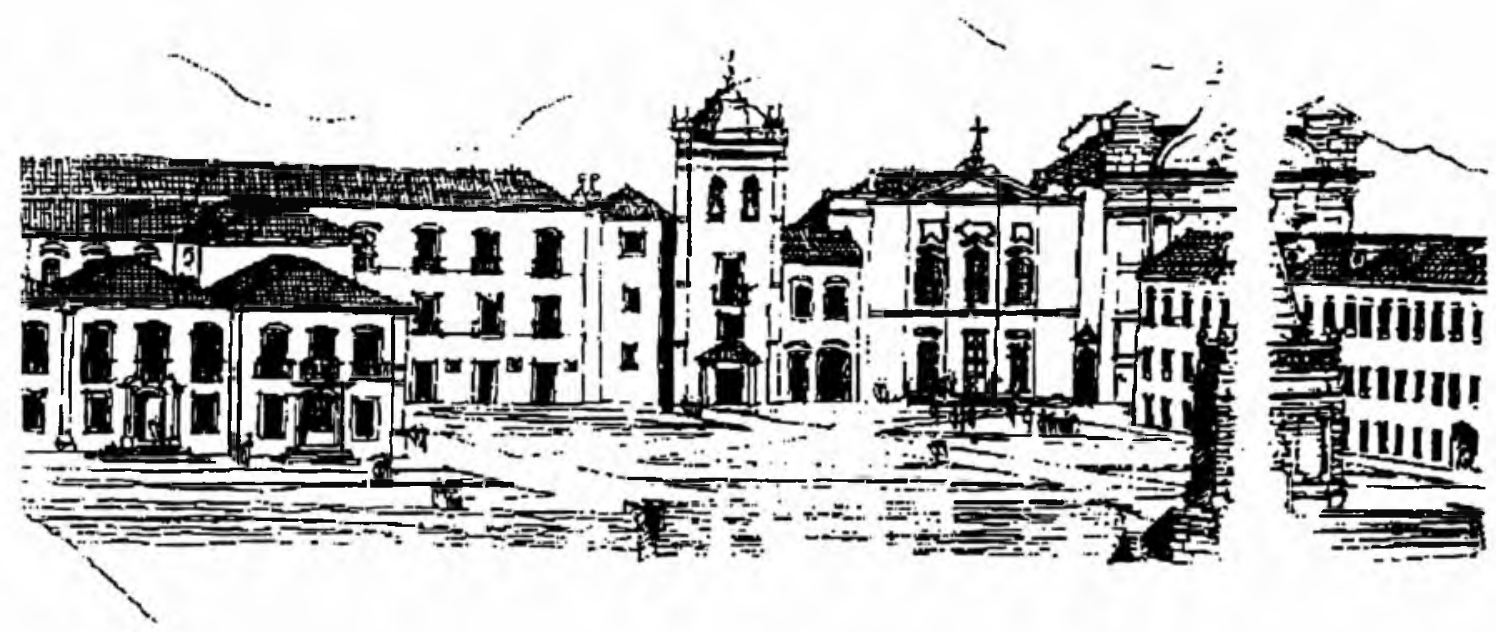

1780

Figura 7 - Vistas da evolução morfologico-espacial da atual área da praça XV de Novembro a partir da fundação da cidade do Rio de Janeiro. /Desenhos do autor, produzidos a partir de pesquisa do IPLANRIO/Núcleo de Memória Urbana em 1988 (1580-1790)

Por outro lado, a permanente mutabilidade da paisagem natural, decorrente das áreas de terreno acrescidas de marinha resultantes do recuo espontâneo do litoral, pelo fenômeno de assoreamento, acrescenta à localização características singulares. 
Com certeza, o marco edificado de maior peso e permanência na configuração deste espaçó foi a sede do poder, inicialmente a Casa dos Governadores, logo Paço dos Vice-Reis (após 1763) e posteriormente elevado à categoria de Paço Real, impropriamente "re-batizado" no presente de "Paço Imperial"

Deve-se, porém, reconhecer que, independente do inegável valor simbólico de tal marco, serão os marcos religiosos que adquirem um maior destaque sobre $o$ ponto de vista de elaboração formal, salvo a rara exceção do chafariz do mestre Valentim.

A propósito, será durante a administração do Vice-Rei D. Luiz de Vasconcellos (1779-1790) que serão executadas as primeiras grandes obras de intervenção urbana no Rio de Janeiro, dentre as quais merecem destaque:

1. Aterro da Lagoa do Boqueirão, a partir do desmonte parcial do Morro das Mangueiras, e execução do primeiro parque público na América Latina: o Passeio Público;

2. alargamento e calçamento do largo do Paço (antigo terreiro da Polé) com traçados triangulares em pé-de-moleque;

3. construção de um chafariz, para abastecimento de água doce das embarcaçôes, alimentado por um aqueduto que o conectava ao rio Carioca, evitando que aquelas tivessem que se deslocar mais de uma légua ao norte, na bica dos marinheiros no Mangue;

4. construção de um cais, ao longo da praça até a Ponta do Calabouço, para proteger o chafariz, de autoria do engenheiro sueco Jacques Funck, contratado para estudar e reconstruir o sistema de defesa da cidade;

5. vários aterros de pontos alagadiços da área equivalente a atual praça Tiradentes e ao Campo de Santana, entre outros.

No princípio de Oitocentos, o antigo largo do Paço (ex-largo do Carmo) era, segundo Lúcio Costa entende a partir da iconografia da época, uma "praça nua, composta na melhor tradição e apropriada à formatura militar" 25 .

Precisamente é esta iconografia, em geral, que retrata o duplo sentido simbólico do cais como elemento defensivo e limite entre terra e mar... "no local consagrado de acesso à cidade-sede do poder colonial, e, nessa condição, ponto inicial/terminal privilegiado de trocas entre a metrópole e a colônia"...26

Em 1808, data em que o Rio de Janeiro é elevado à categoria de nova capital portuguesa, situada na mais importante das colonias ultramarinas de Portugal, a configuração espacial do largo do Paço respondia ao seguinte esquema ${ }^{27}$ : 
A identificação do Rio de Janeiro, a partir do séc. XVIII, com a metrópole portuguesa (Lisboa, fica claramente evidenciada na configuração do largo do Paço, cuja filiação ao terreiro do Paço de Lisboa é bem clara ${ }^{28}$.

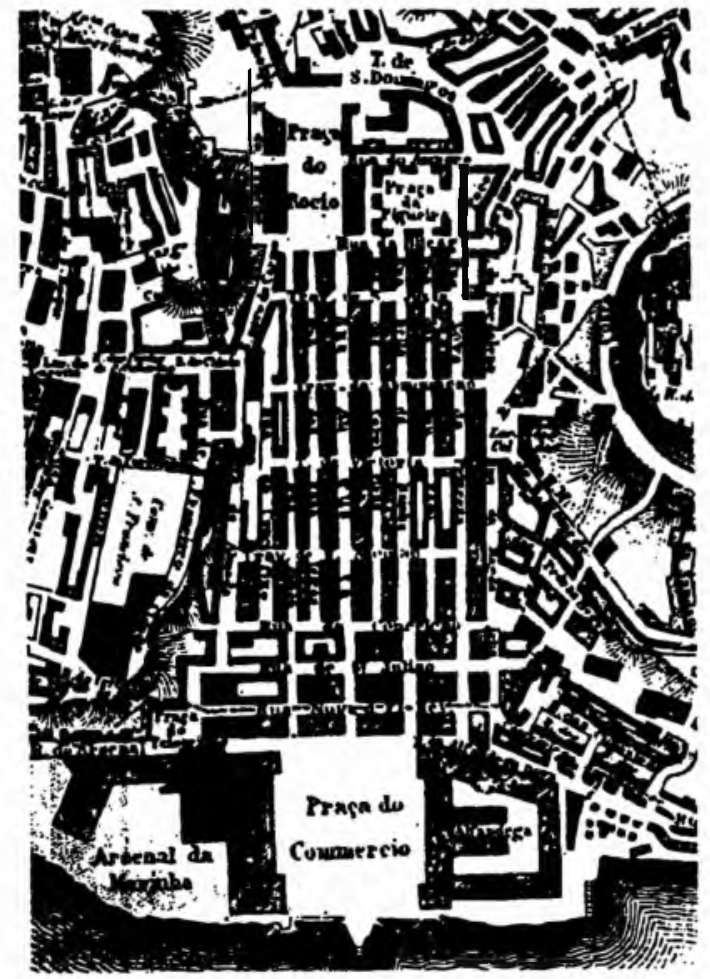

Figura 8 Planta de Lisboa datada de 1833: pormenor da parte baixa da cidade. À beira do Tejo fica a "Praça do Commercio", seguindo-se a ela um traçado viário regular recobrindo a parte baixa da cidade, delimitada pelas colinas de São Jorge, a direita, e de São Francisco, à esquerda

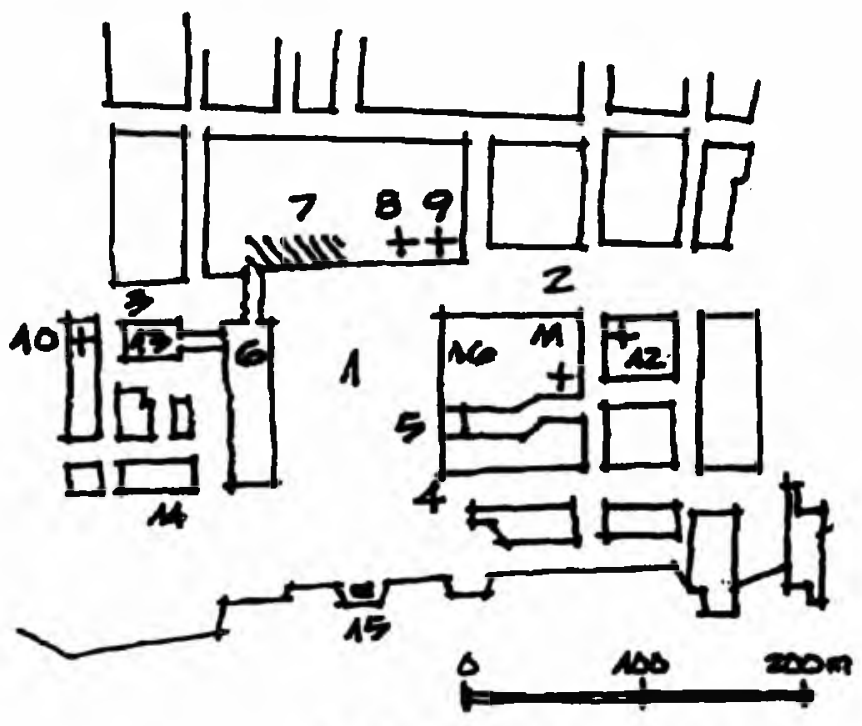

1. Largo do Paço . 2. Rua Direita 3. Rua da Misericórdia 4. Rua do Mercado 5. Arco do Teles 6. Paço Real

7. Convento do Camo 8. Igreja do Convento 9. Igreja dos Terceiros do Camo 10. Igreja de São José

11. Igreja de N. Sra. da Lapa dos Mercadores 12. Igreja da Santa Cruz dos Militares 13. Câmara e Cadeia

14. Teatro 15. Chafariz 16. Sobrados dos Teles de Menezes

(seg. SISSON, Rachel, in "Marcos Históricos e Configuracōes Espaciais - Um estudo de caso: Os Centros do Rio de Janeiro"/Arquitetura Revista n. 4/NPD-FAU/UFRJ. Rio de Janciro. 1986.

\section{EAM dE GAANAEARA}

A Praça XV de Novembro (Largo do Paço) em começo do século XIX. 
Assim, o conjunto composto pelo chafariz e as muretas e escadarias do cais tendo como pano de fundo ora a perspectiva da praça, com o convento do Carmo ao fundo, ora a linha do horizonte no mar, tornou-se, por assim dizer, no típico cenário/suporte representativo da "Porta do Brasil" e do poder, durante boa parte do séc. XIX.

Mas já por volta de 1840,0 inexorável processo natural de assoreamento foi gradativamente afastando o chafariz do mar e das embarcações, além de encobrir parcialmente as muralhas e escadarias do cais, sendo necessário um bicame de madeira mais extenso para levar a água aos botes.

Será em 1870, durante o Primeiro Império, que o cais sofrerá sua primeira grande reforma, afastando definitivamente o chafariz do mar, com a construção do projeto do arquiteto Adolpho José Del Vecchio, também autor do edifício em estilo eclético da antiga estação das barcas da cantareira (posterior entreposto de pesca), denominado cais Pharoux, em homenagem ao Hotel Pharoux situado na beira do antigo.

O acostadouro atual é obra da República, concluído na primeira década do séc. $\mathrm{XX}$, assim como $\mathrm{o}$ ajardinamento da praça nos moldes da escola francesa filiada a A. Alphand engenheiro paisagista a serviço do Barão Haussman, na reforma de Paris introduzida em nosso meio pelo engenheiro paisagista Auguste Marie Glaziou, trazido pelo imperador D. Pedro I para a reforma do Passeio Público em 1868.

Desta forma, o chafariz do mestre Valentim, totalmente descontextualizado da sua função primeira (abastecer de água potável as embarcações) acabou ilhado dentro do grande espaço resultante, emoldurado por um perímetro marcado inicialmente, por uma área gramada, e transformada posteriormente, até 1988, em espelho d'água.

Somando-se a esta acentuada descaracterização, uma vultosa obra executada por volta dos anos 60, veio definitivamente seccionar a área criando uma barreira não somente física, mas também visual: a avenida Perimetral.

Esta infeliz obra, que estabelece a ligação do aterro do Flamengo (zona sul) com a avenida Brasil (zona norte), colocada como opção para o projeto da ligação Norte-Sul proposto pelo arquiteto Affonso E. Reidy, no final da década de 40, produz um violento corte na praça XV de Novembro e em todo o trecho da faixa litorânea de inestimável valor, sob o ponto de vista da história da cidade do Rio. 
Finalmente, uma passarela para pedestres, sob o viaduto da av. Perimetral transversal a este, completa, na década de 70 , o conjunto de elementos que interferem seriamente, em termos de leitura visual, na percepção do sítio histórico.

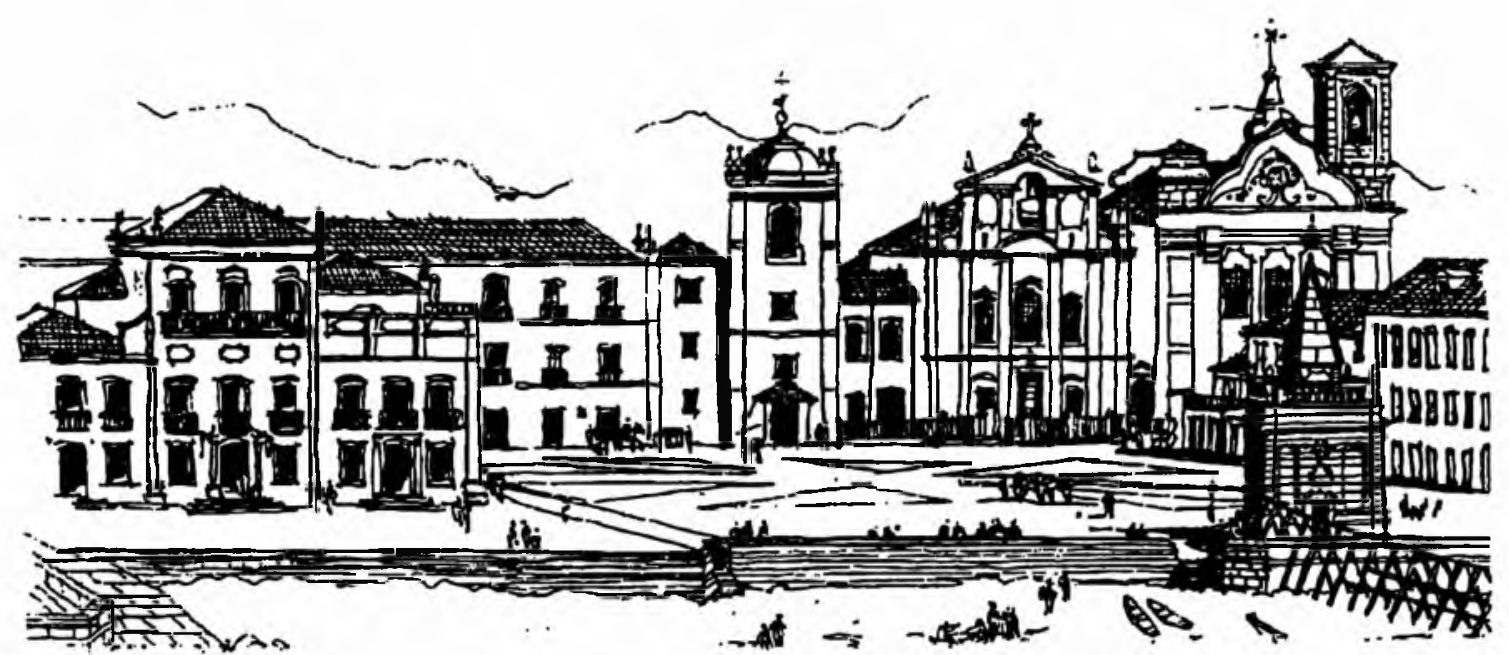

1840

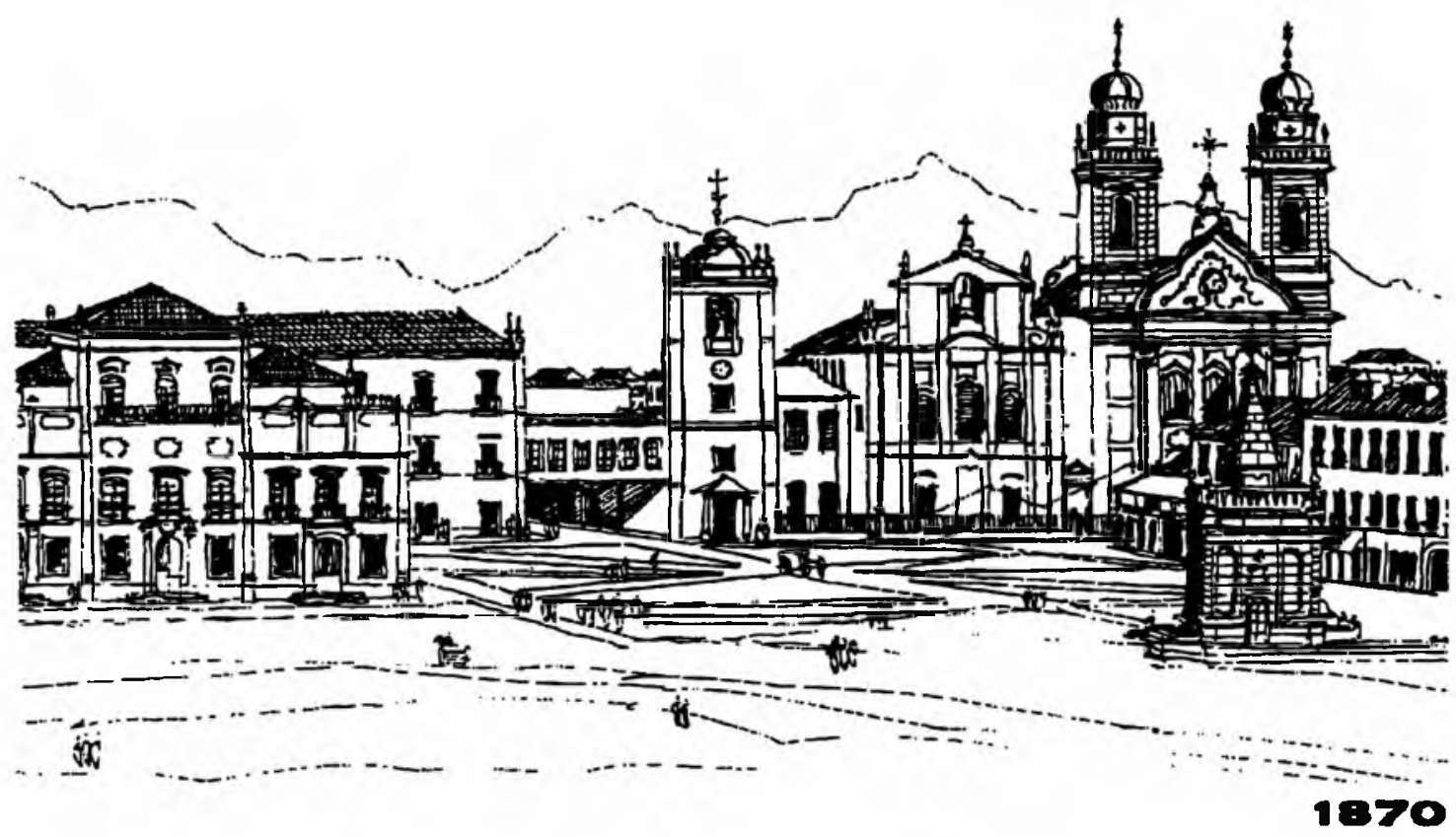



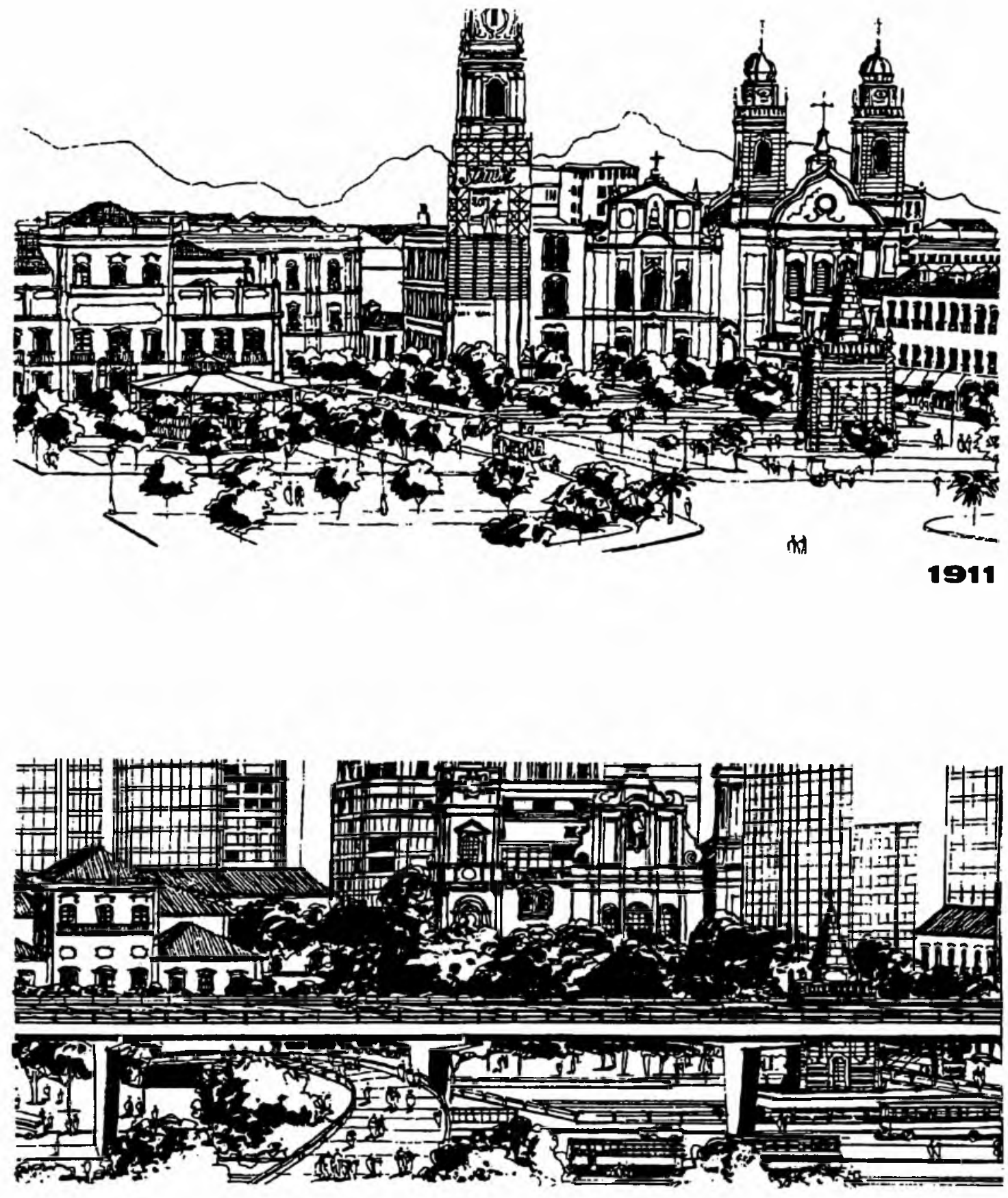

1990

Figura 9 - Vistas da evolução morfológico-espacial da atual área da praça XV de Novembro de 1840 a nossos dias /Desenhos produzidos pelo autor a partir de pesquisa do IPLAN-Rio/Núcleo de memória urbana em 1988 


\section{A RECUPERAÇÃO DO VELHO CAIS E SUẢ INCORPORAÇÃO A UMA NOVA REALIDADE ESPACIAL}

O velho cais do largo do Paço, que durante dois séculos foi o principal porto de ligação do país com o resto do mundo, passou por uma série de escavações arqueológicas que, em 1987, fizeram reaparecer os elementos componentes da sua estrutura básica, resgatando com isso a leitura popular mais importante da história da cidade.

As escavações foram iniciadas no segundo semestre de 1986, orientadas, em princípio, pelas hipóteses conjecturais tecidas pelo arquiteto Antônio Pedro de Alcantara, consultor do SPHAN, construídas a partir de uma pesquisa, na ocasião incompleta, baseada na vasta iconografia existente sobre a praça XV no séc. XVIII, época em que passou a constar da paisagem da cidade.

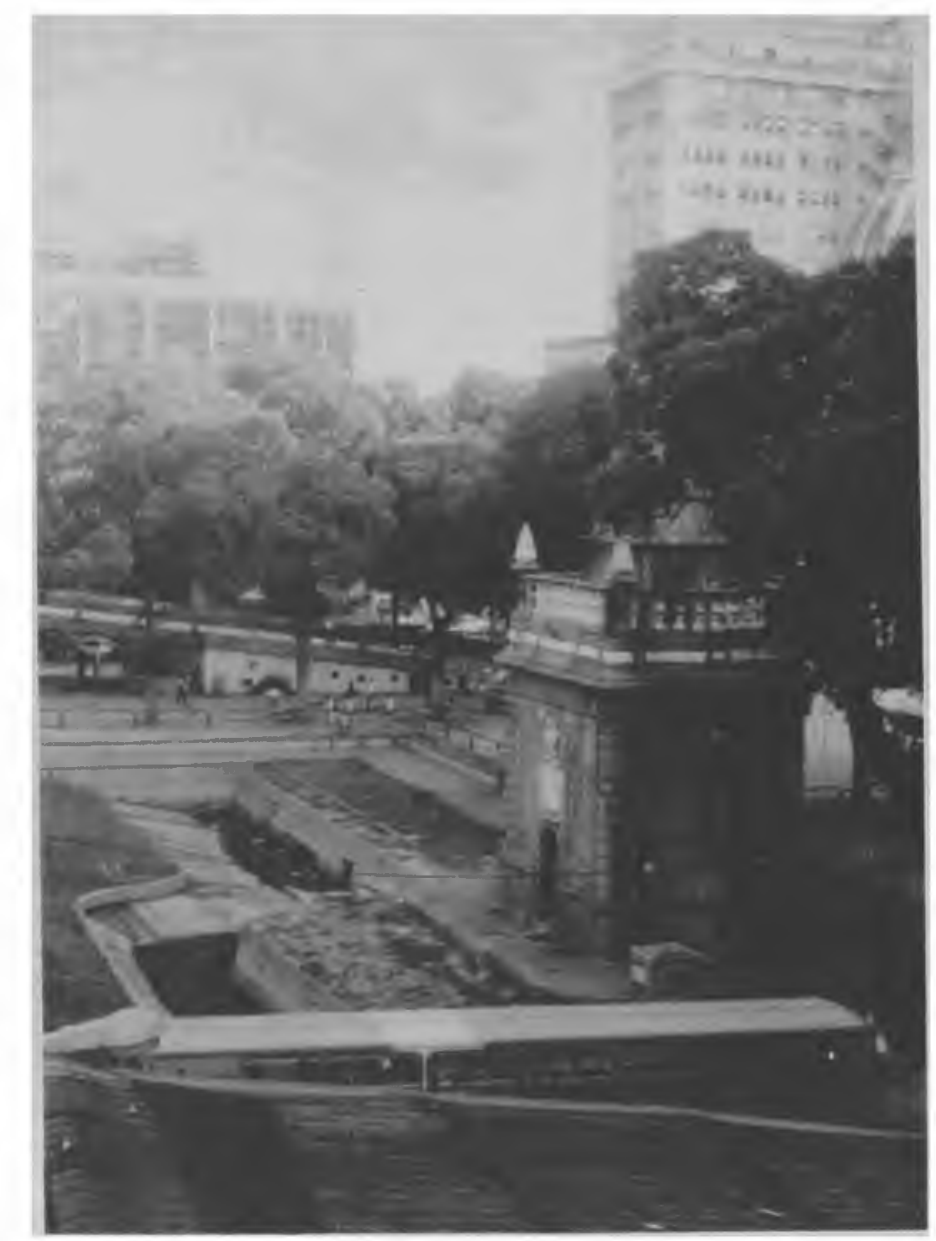

Foto O chafariz da praça XV, no seu estado atual (1993) segundo o projeto do SPHAN/PRÓMEMÓRIA 


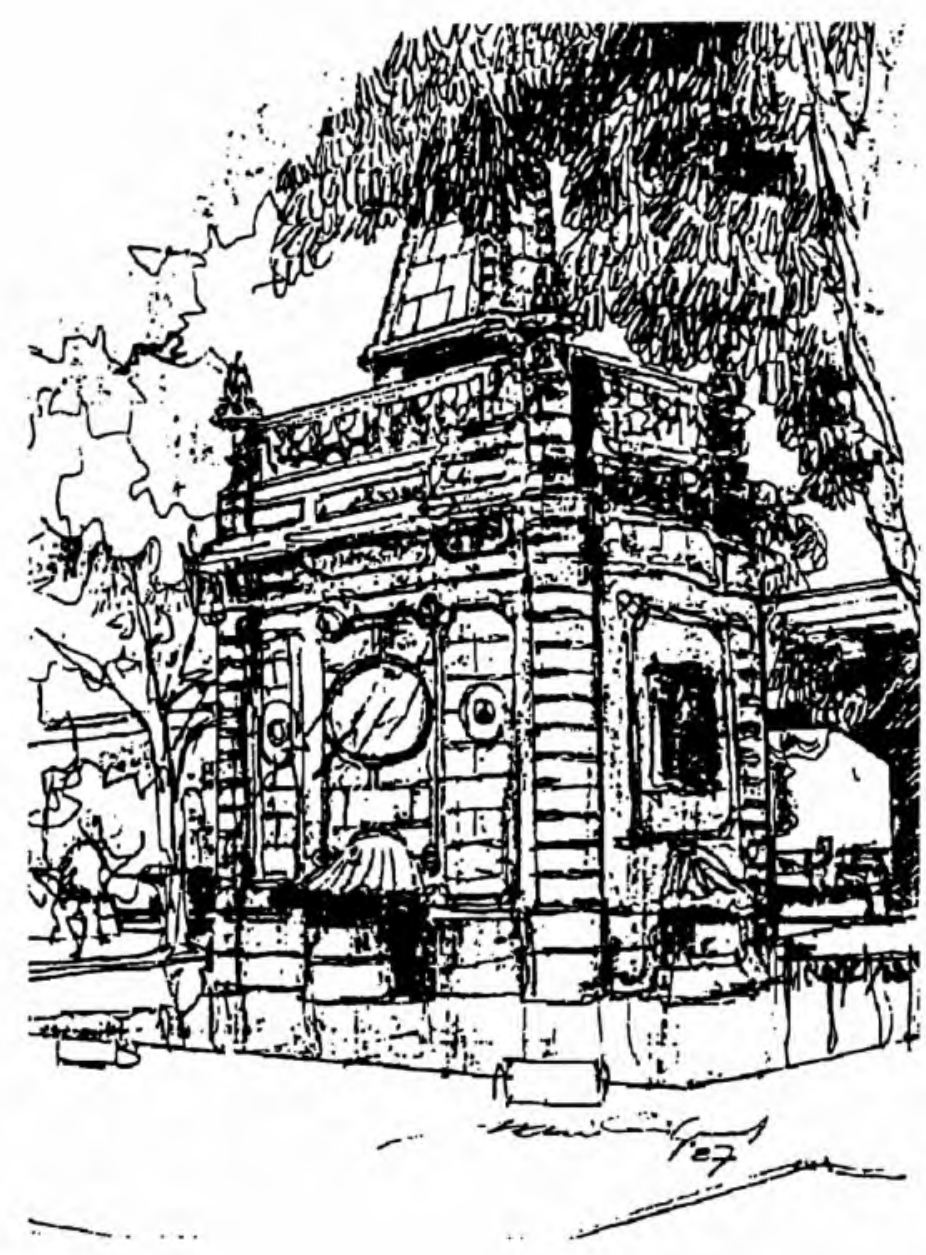

Figura 10 Vista do chafariz da praça $\mathrm{XV}$, segundo croquis do autor, prévio ao início das obras de escavação, do interior da praça. Ao fundo a avenida Agache e o viaduto da avenida Perimetral (1986)

Somavam-se, também, a este material de referência, as diferentes propostas de projeto apresentada pelo engenheiro militar sueco Jacques Funck ao Vice-Rei D. Luiz de Vasconcellos, e desenhos a bico-de-pena aquarelados com inclusão, ainda, de orçamentos detalhados, pertencentes ao acervo de obras raras da Biblioteca Nacional.

Não existia, porém, nenhuma certeza daquilo que iria, de fato, ser encontrado, e não foi pouca a satisfação dos envolvidos no projeto, quando apareceram os primeiros degraus das escadarias em cantaria do cais, após alguns meses de trabalho, que seriam aquelas utilizadas para o desembarque da família real, em 1808 , bem em frente ao chafariz projetado por mestre Valentim.

Mesmo assim, após estas constatações, permanecia a indefinição sobre a continuidade da obra, e dos limites e cronograma ou etapas da escavação, como decorrência de vários fatores internos e externos: 


\section{A incerteza da existência integral do restante do cais;}

2. a dificuldade de liberação de verba a partir de um projeto estruturado em bases conjecturais;

3. a inexperiência neste tipo de obra escavação arqueológica carência de equipamentos específicos e de pessoal especializado disponível;

4. a incompatibilidade entre o "tempo" do trabalho arqueológico extremamente demorado e delicado e a premência do administrador, pressionado por uma política de resultados, em função do jogo eleitoral;

5. a necessidade de uma pesquisa profunda e detalhada, que foi desenvolvida paralelamente ao trabalho;

6. os limites físicos existentes, principalmente a Bolsa de Valores do Rio de Janeiro, o anexo da Assembléia Legislativa, a passarela sob o viaduto da avenida Perimetral, a avenida Perimetral e o terminal de ônibus e a passarela de pedestres sob a mesma;

7. o impacto da escavação sobre o desconhecido traçado da rede de infra-estrutura subterrânea, assim como a permanente infiltração da água do mar.

\section{PROJETOS E FILOSOFIAS}

Desde o começo deste projeto, duas correntes de pensamento surgiram bem nítidas e, de certa forma, antagônicas no que se refere ao conceito que iria definir a problemática que uma obra como esta envolvia.

Um destes grupos, mais ligado à uma formação "histórico-arqueológica" entendia com razoável procedência que uma obra desta natureza não poderia ser interpretada nos moldes típicos de uma simples obra de restauro: a escavaçāo, em si mesma, e o processo de pesquisa arqueológica eram, de fato, a "peça" a ser exibida, antes que a reposição (incompleta) do conjunto "cais-chafariz"

De acordo com este enfoque, a quarta dimensão o tempo - adquiria uma relevância ímpar, como forma didática de socialização, não só da memória erudita, mas também da mecânica do seu resgate.

Em contrapartida este grupo ignorava, em termos concretos, o grau de exeqüibilidade construtiva e o impacto de tal obra no contexto da praça $\mathrm{XV}$, como conjunto, além da forma de participação e fruição efetiva da obra, por parte do usuário final, minoritariamente erudito. 
Dissociava-se, assim, o fato histórico do contexto urbano existente, e o estudo dos contornos que iriam adquirir a nova situação em termos de configuração espacial e uso, num sentido mais amplo, eram, portanto, relegados a um segundo plano.

Já um outro segmento, mais ligado à corrente dos arquitetos mais antigos do O-DGPJ, direta ou indiretamente filiados à corrente de profissionais formados na sombra do lendário "Grupo de Trabalho do Parque do Aterro do Flamengo" na década de 60 - marco indiscutível do paisagismo carioca tinham sérias dificuldades em aceitar a abordagem dos "arqueologistas"

A obra, por esta ótica, devia ter um limite fixo, acabado e "neutro" a ser conseguido através de uma forma geométrica simples e "sóbria" que permitisse uma leitura "natural" da área recuperada.

Era o objetivo claro de tal posição, reduzir o impacto visual da intervenção arqueológica, visando a incorporação imaginária, no sentido lacaniano, da percepção da obra por parte do usuário.

Numa posição radicalmente oposta ao grupo anterior, esta filosofia de projeto, embora comprometida com a viabilização construtiva, sacraliza a mimese como objetivo de trabalho e o "receituário" de linguagens de projeto preconcebidas como mecânica operativa, independente da temática, na configuração da paisagem urbana.

Particularmente concluímos, na época, a partir de ambas posições, que independente da relevância da(s) "peça(s)" a ser(em) exibida(s), que o histórico da localização evidenciava claramente, a questão da definição da retórica da exibição das mesmas era de importância vital.

De fato, tratando-se a área em questão uma das mais antigas da cidade e que representa, como vimos, uma superposição de diferentes épocas e marcos, o nível de "ruídos" indesejáveis, dificultavam a definição de uma dialética expositiva.

Por outro lado, devido à praça estar situada defronte do maior terminal hidroviário da cidade (a estação das barcas Rio-Niterói-Paquetá-São Gonçalo) que movimenta, nos horários de pique, milhares de usuários de tais serviços, que teriam que passar pela área em questão a caminho do "core" financeiro do Rio, incorporava uma massa de "receptores" em potencial, cuja permanência muito curta limitava a transmissão da mensagem a um nível quase subliminar. 
Outrossim, uma parcela menor do público, porém não menos significativa, constituída por aquele segmento que naturalmente (pela proximidade do local) usufrui da praça diariamente, na hora do almoço, vindo do setor comercial e financeiro que domina as adjacências, nos apresentava um usuário real e potencial, que teria um nível de permanência bem maior.

Fenômeno similar pode ser apreciado em outros poucos espaços livres públicos como, por exemplo, o "pilotis" do edifício do Palácio da Cultura / ex-MEC.

Era nossa idéia, portanto, que qualquer alteração na configuração geral da praça - particularmente no que se refere à escavação arqueológica e à informação que dela surgisse deveria ser fortemente denotada como forma de recortá-la de um contexto espacial confuso - o "ruído" - e de atrair a atenção sobre a descoberta.

Tal denotação era por nós vista, na época, funcionando em dois níveis claros de participação: o primeiro, mais imediato, dar-se-ia através da percepção, marcada pela forma e pela cor, ora no contorno do sítio arqueológico, ora no tratamento do atual piso da praça; no segundo nível de comunicação seriam privilegiados aspectos de uso diversificado - funcional - incluídos no contexto do próprio sítio, tais como exposição permanente, venda de material de divulgação sobre a obra e a localização, lazer contemplativo, teatro ao ar livre, por exemplo.

\section{AS PROPOSTAS APRESENTADAS}

Além das questões relacionadas à definição do sítio arqueológico, uma outra de igual grau de complexidade e relevância conduziu a discussões acaloradas.

É um fato que a relação biunívoca entre um cais e água é, genericamente, óbvia e, portanto, indiscutível. Mas, como pôde ser apreciado no histórico da área, esta relação foi se alterando progressivamente no decorrer dos anos, por fatores naturais (fenômeno de assoreamento) e por intervenções da mão do homem (aterros sucessivos).

Se somarmos a estes fatores os elementos construídos de peso que se interpuseram entre a área do antigo cais e o mar, no séc. XX (estação das barcas, viadutos da avenida Perimetral, passarela de pedestres e a própria massa arbórea da reforma de 1911, que além de travestir o caráter tradicional da praça, sacralizaram essa dissociação visual com o mar), poderemos concluir que qualquer proposta de recomposição física da relação "cais-mar" não passa de um exercício de retórica erudita inconseqüente. 

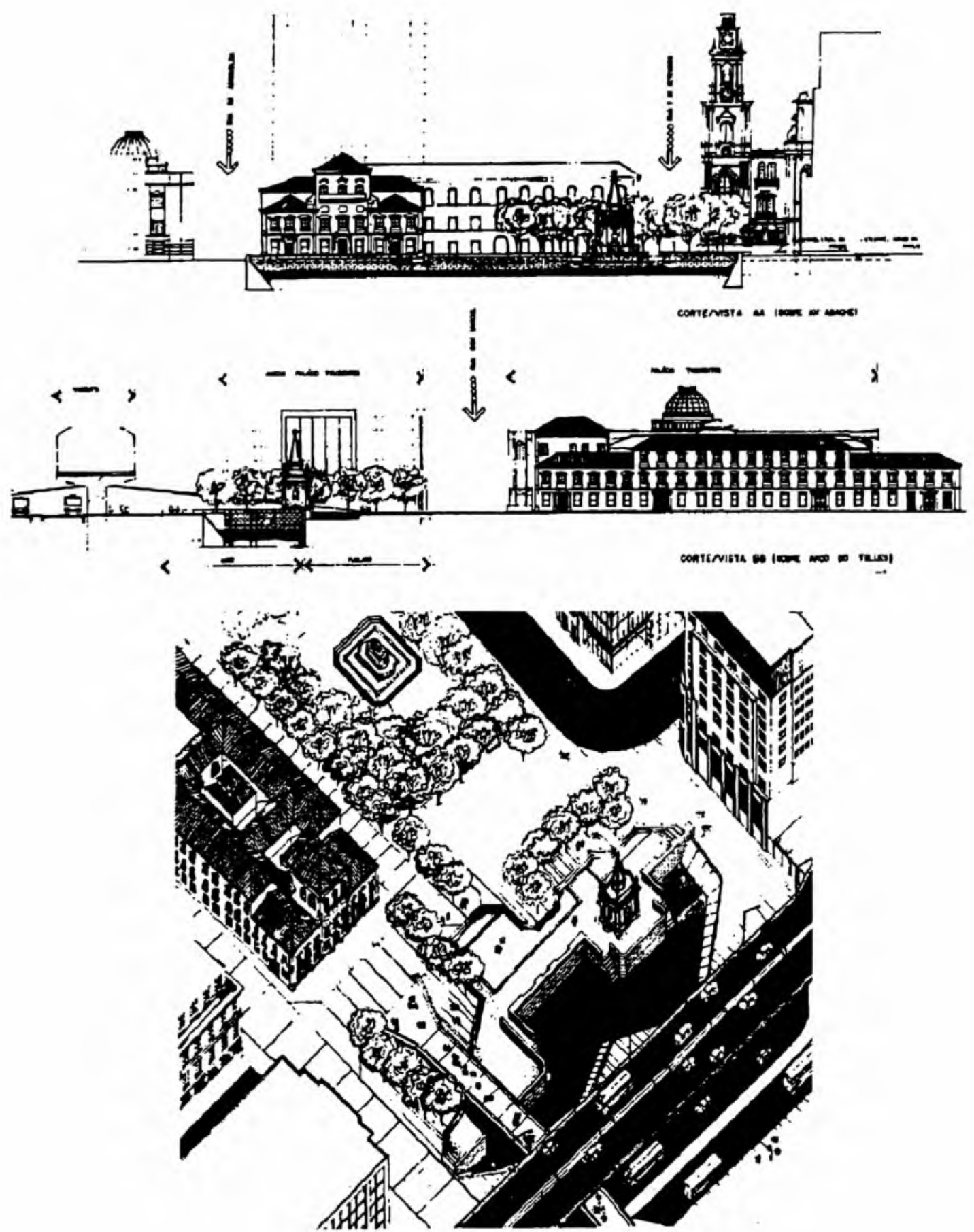

Figura 11 Recuperaçāo e proposta urbanístico-paisagista para a área da praça XV de Novembro afetada pelas escavaçōes para descoberta do antigo cais do Rio de Janeiro, em trabalho conjunto com o SPHAN (Serviço do Patrimônio Histórico e Artístico Nacional) Rio de Janeiro/1987/1988

Por outro lado, a leitura das ruínas descobertas, como "cais" era profundamente prejudicada por tal situação, muito mais facilmente associada a uma muralha defensiva do que com o antigo porto da cidade. 
A água do mar que naturalmente aflorava na área de escavação, infiltrada por entre o solo arenoso, nos forneceu um dado de inestimável valor para tentar resolver este problema.

Mesmo na época em que o mar batia na murada do cais, a mutabilidade do seu perfil, a partir da alteração das marés e do gradativo assoreamento como decorrência da ação das correntes marinhas sobre o particular contorno desse trecho da orla, era permanente.

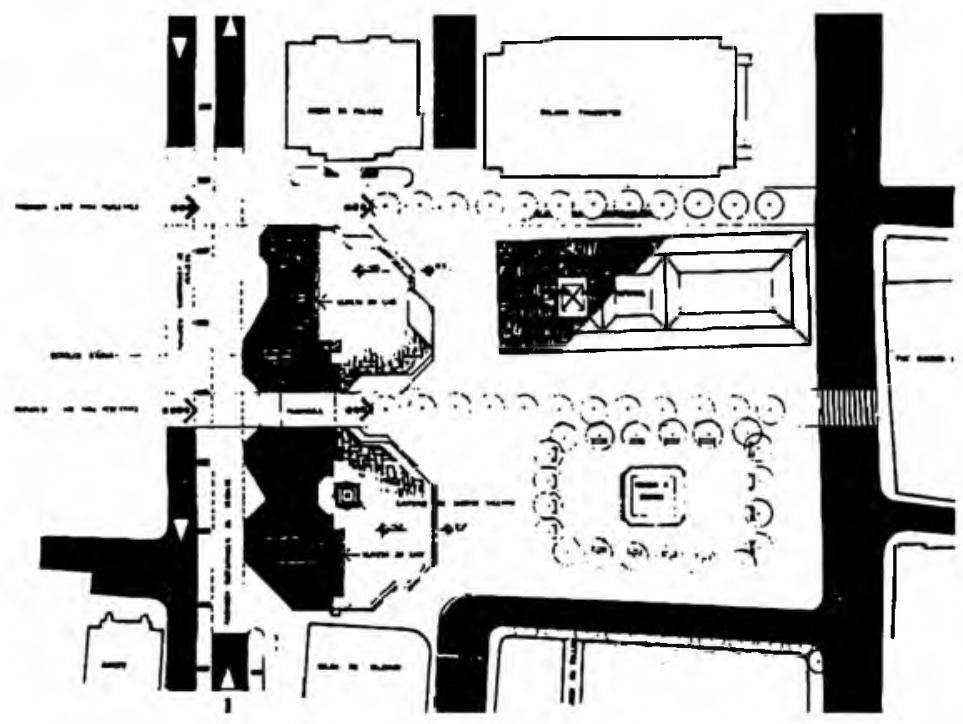

Figura 12 Primeira alternativa apresentada pela equipe do O-DGPJ sugerindo a passagem subterrânea da avenida Agache, para integrar o piso da praça à esplanada da estação das barcas e demoliçāo da passarela para pedestres

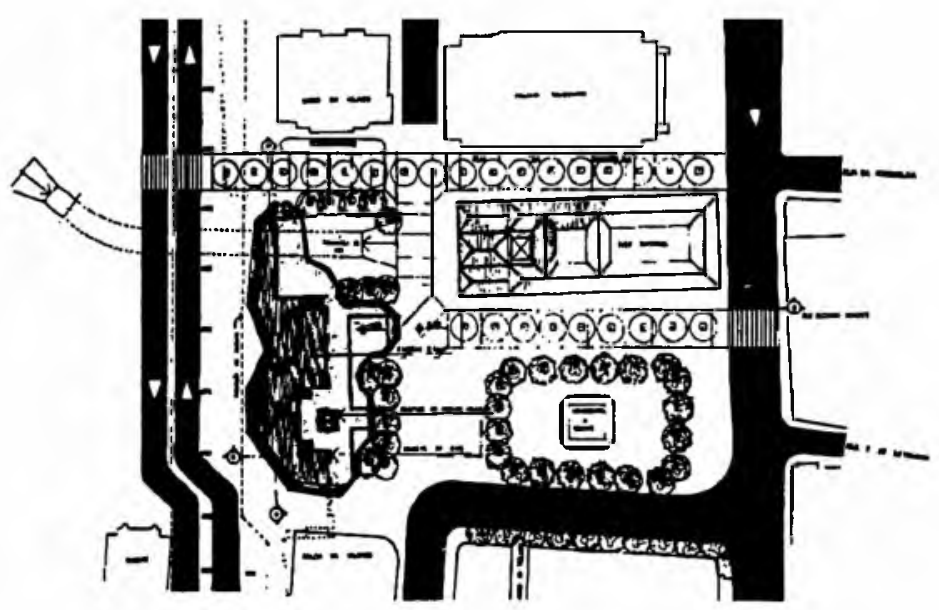

Segunda alternativa apresentada pela equipe do O-DGPJ, mantendo ainda a rua da assembléia como limite da escavação, e a manutenção da passarela de pedestres 
Estas mutações, retratadas com freqüência pelos pintores viajantes nos sécs. XVIII e XIX, principalmente, representam uma chave importante para a interpretação desta variada iconografia e dos diversos usos que o conjunto teve no decorrer do tempo.

Nossa proposta visava aproveitar a água infiltrada do mar, invadindo parte do perímetro do sítio arqueológico (aquela que originalmente pertencia à baía), por um sistema de vasos comunicantes e filtros naturais (bidim), de forma que a lâmina d'água que assim resultasse, sofresse, no decorrer do dia, variações de nível similares às oscilações das marés.

Assim, estas oscilações evidenciariam, ora a muralha do cais e escadarias parcialmente encobertas pela água, ora a sua totalidade, até deixar em evidência o "enrocamento" conjunto de rochas de grande volume colocadas próximas aos alicerces do cais na maré baixa.

No que se refere à definição dos limites do sítio arqueológico, interpretávamos que na medida que a própria escavação representava uma cisão ou "corte" da superfície do atual piso, para expor as "entranhas" representativas da história da cidade, deveriam seus contornos estar assimilados plasticamente à idéia de "rasgo" de uma "pele", acentuado, inclusive, pelo uso da cor e/ou textura.

A denotação desta fratura, portanto, agiria como marco divisório entre duas épocas: o séc. XVIII e o séc. XX. A sua materialização dar-se-ia por uma cortina de concreto de traçado irregular, necessária para conter o solo de fraca consistência, com uma leve inclinação de $60^{\circ}$ e uma pigmentação incluída na sua massa.

Esta cortina somente seria interrompida na proximidade da estrutura original do cais, à guisa de junta de dilatação, reduzindo, assim, a possibilidade de algum dano acidental da mesma.

Assim mesmo, visando facilitar a visão frontal do cais e criar as condições mínimas de perspectiva, foi proposta a ampliação da calçada do lado da cortina de concreto, às custas de parte de uma das pistas da avenida Alfredo Agache, que teria seu fluxo de trânsito sensivelmente diminuído pelo deslocamento de pontos de ônibus motivo de freqüentes congestionamentos para o novo terminal da Misericórdia, de autoria do arquiteto Jaime Lerner.

Por fim, em função do usuário mais freqüente, uma áreà de exposição permanente, mostrando a iconografia, a cartografia e a material fotográfico que retratasse a evolução da área, deveria ser montada no próprio sítio arqueoló- 
gico, no patamar representativo do nível original do antigo largo do Paço, possibilitando, inclusive, a encenação de peças de teatro, especialmente à noite, com o cais e o chafariz como cenário.

Em consequiência, a "peça" (o conjunto arquitetônico), dependendo da circunstância, agiria tanto como "fundo amorfo" quanto como figura.

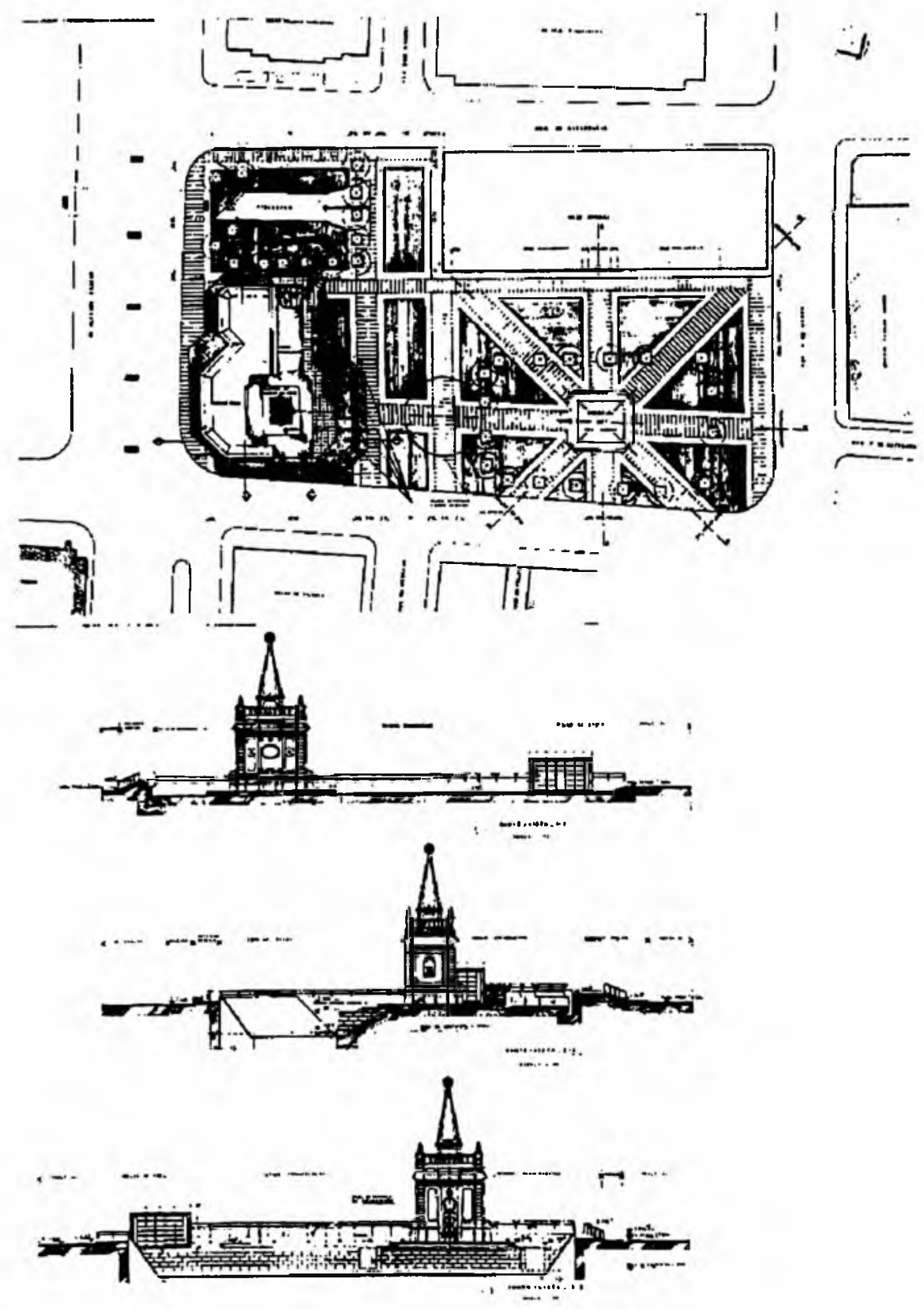

Figura 13 Projeto final apresentado pela equipe do O-DGPJ, incluindo a recuperação do antigo traçado do piso da praça, em pedra portuguesa branca, preta e vermelha 

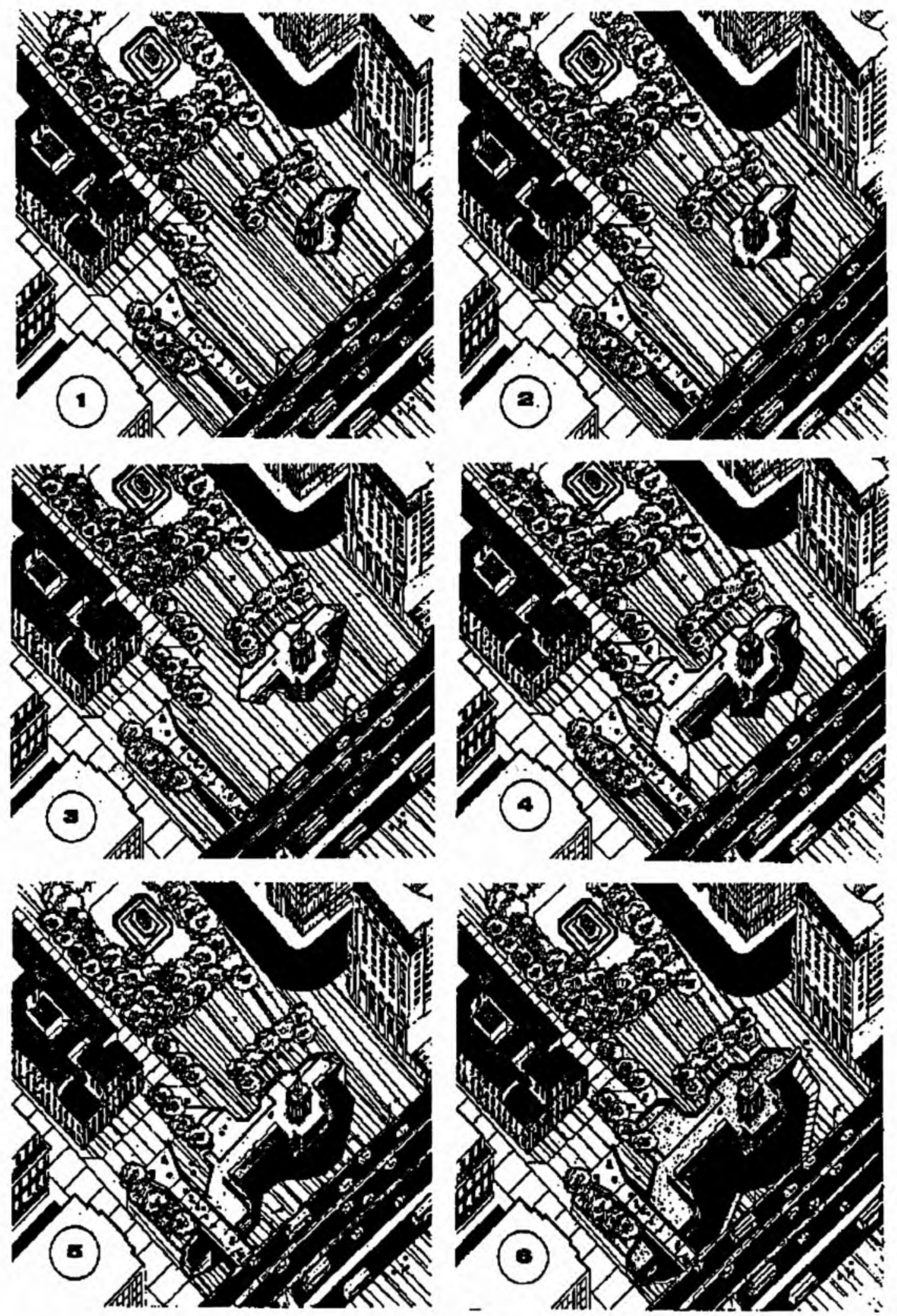

Figura 14 - Seqüência ilustrativa da geração da idéia que originou o perfil fraturado proposto para os limites do sítio arqueológico, coincidente com as etapas de evolução da obra (Desenho do autor) 


\section{A PROPOSTA EXECUTADA}

Finalmente a incompatibilidade, antes assinalada, entre a demanda de tempo exigida pela naturalmente demorada pesquisa arqueológica e a urgência de resultados por parte do administrador (a Prefeitura), somadas a não poucas vaidades em jogo, face à disputa pela paternidade do empreendimento, conduziram a uma interrup̧̧ão peremptória dos trabalhos em andamento, particularmente a coleta e a indexação da numerosa, variada e rica coleção de peças que ia surgindo do trabalho de escavação.

Um outro projeto, elaborado pela empresa construtora, tradicional empreiteira de obras para o município, a partir de um outro desenvolvido, em paralelo, pela equipe do SPHAN, foi finalmente executado, jogando por água abaixo todo o cuidado e ricas discussões que tinham se originado desde o começo dos trabalhos.

Nesta proposta, além da área ter sido cercada e, portanto, eliminada sua ocupação para qualquer uso, o setor correspondente à lâmina d'água foi resolvido com um extenso e custoso tanque de concreto vedado, com um sistema de bombas para filtragem e limpeza da água ali colocada.

Porém, a impossibilidade de se impermeabilizar totalmente tal laje, em pouco tempo permitiu a infiltração da água do mar - sem tratamento - e a conseqüente criação de microorganismos na água estanque, adquirindo a natural coloração turvo-esverdeada. A permanente desativação das bombas, por ausência de manutenção, agravou, mais ainda, o problema.

O perfil do sítio arqueológico, seguindo o alinhamento das calçadas, se define a partir de um "sóbrio" contorno regular, resolvendo com dois taludes e um "patamar" intermediário, gramado, o desnível existente entre a calçada da avenida A. Agache e o nível da lâmina d'água.

Ficam, ainda, como subproduto negativo de tal obra, o rejuntamento das pedras do "enrocamento" com massa e o forte abalo que a própria estrutura do chafariz sofreu na sua estrutura, como decorrência do uso de maquinaria pesada escavadeira mecânica, entre outras que iria consumir, posteriormente, uma quantia considerável para sua recuperação.

Atualmente, o mencionado conjunto acabou sendo incorporado ao imaginário, não da forma que foi cogitada inicialmente, e sim como um problema não resolvido, a partir de sua precoce decadência e aspecto de abandono. 


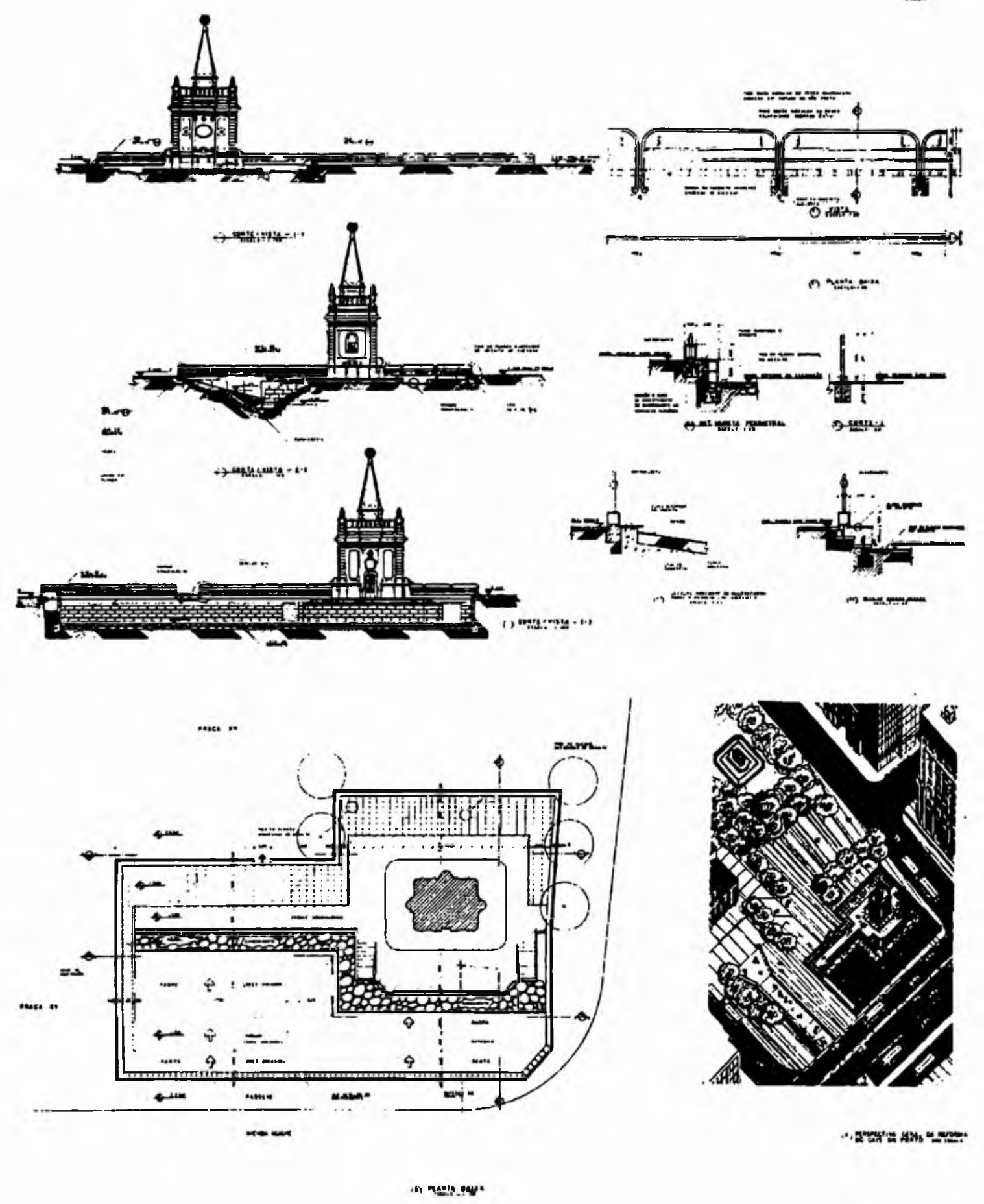

Figura 15 Projeto apresentado em forma isolada pelo SPHAN/PRÓ-MEMÓRIA, em 1987 e, posteriormente, executado 


\section{CONCLUSŌES}

A abordagem das questões levantadas, inseridas num sentido mais amplo ora no campo do desenho urbano, ora no paisagismo, ou ainda nas problemáticas comunicacionais e/ou semióticas do espaço da cidade, refere-nos, principalmente, à questão da multiplicidade e da justaposição de leituras que a paisagem urbana nos propõe e o lógico grau interdisciplinar que as mesmas supõem, à luz da nossa praxis projetual.

Esta proposta conceitual basea-se, fundamentalmente, na incorporação da noção de memória - e seus mecanismos de fixação e recuperação de sensações, pensamentos e/ou imagens tanto como um marco teórico para compreensão do processo de leitura da paisagem, quanto como componente metodológico no processo de desenho ambiental.

Consideramos tal postura mais completa que aquelas que usualmente privilegiam o uso do processo perceptivo como forma única de compreensão dos mecanismos humanos de seleção, organização e interpretações do (...) "estímulo sensorial em imagens coerentes e significativas do Mundo"... ${ }^{29}$

Em última análise, trabalhar com o projeto da paisagem, significa, em boa parte, embrenhar-nos nos próprios processos de construção da afetividade e, portanto, nos atos do psiquismo e das suas variáveis sócioculturais, condicionantes dos aspectos funcionais ou de uso envolvidos na sua configuração espacial.

Feitas estas ressalvas, podemos entender que o processo perceptivo funcionaria, assim, como uma fonte permanente de estímulos externos positivos ou não da psique, que pela sua reiteração (redundância) acabariam estabelecendo uma relação imaginária com os indivíduos.

Entretanto, na medida em que tais questões envolvem uma problemática inerente ao espaço público, elas nos colocam "face-a-face" com a realidade da praxis projetual no seio da gestão pública, pela abrangência das intervenções, e com as diversas instâncias de decisão - em boa parte políticas - como manifestação direta de interesses setoriais.

Nesta escala do projeto da paisagem, alia-se aos condicionantes anteriores, e com maior ênfase, o grau de negociação, ou melhor, de verdadeiro gerenciamento de interesses a que deve proceder o profissional de projeto - 0 arquiteto - 
aspecto que, sem exageros, deve ser incorporado como um requerimento a mais de qualquer programa de necessidades.

Sem uma consciência clara desta questão que implica o grau de responsabilidade assumido, ou não, pelo arquiteto - e do conseqüente recorte ideológico que a decisão de projeto supõe, o "desenho/desígnio" da paisagem assumirá os contornos alienados de uma prática inconsequiente, em termos de otimização das qualidades ambientais do espaço urbano.

O que afirmamos, não supõe da nossa parte um posicionamento ingênuo acerca do real grau de ingerência do arquiteto sobre a configuração espacial da paisagem da cidade, particularmente quando integrante dos próprios quadros técnicos da administração pública, e sim a relevância do estabelecimento de uma hierarquia de valores dos elementos a serem defendidos e/ou negociados, estabelecendo assim os limites do "inegociável"

O projeto apresentado neste artigo, que se insere na problemática proposta, teve o objetivo de proceder de forma clara ao recorte ideológico mencionado.

Ele tenta incorporar uma idéia, cada dia mais aceita no contexto dos problemas da memória urbana, que consiste na proposta da apropriação dos monumentos pela população, antes que sua simples exposição.

Incorporado assim o monumento ao uso cotidiano e, portanto, ao imaginário coletivo (contextualizado historicamente), seria recuperada uma memória coletiva urbana perdida e realimentada uma consciência "regional/urbana" através da busca e da denotação das referências perceptuais que de forma mais imediata pudessem estabelecer um processo comunicacional com seus habitantes pelo tratamento museológico da paisagem histórica da cidade.

\section{NOTAS}

(1) Cabia-nos na ocasião, dentro da superintendência de paisagismo do O-DEPJ, a função de estudar e coordenar todos os projetos de paisagismos desenvolvidos no centro do Rio de Janeiro, no período.

(2) O projeto do Corredor Cultural aprovado por Lei Municipal no 506 de 17/01/84, define... "as condições básicas para a preservação paisagística e ambiental de grande parte"... do centro histórico do Rio de Janeiro (p. 6 do Manual do Corredor Cultural).

A lei também instituiu uma comissão permanente O Grupo Executivo do Corredor Cultural / RIOARTE - que ficou encarregada da fiscalização e do comprimento integral dos dispositivos legais. 
Trata-se, segundo seus autores, de ... "um projeto de preservação, renovação e revitalização"... que propõe, através de sua legislação e normas ... "proteger o conjunto arquite tônico antigo e orientar a inserção de novas construções"... (p. 8, op. cit.).

(3) O O-DGPJ agiu em co-gestão com o ex-SPHAN através do seu consultor o arquiteto Antônio Pedro de Alcântara.

A associação deste órgão justificou-se na medida que a referida área envolvia jurisdição da competência de ambos: como área de praça (O-DGPJ) e como área tombada pelo patrimônio federal (SPHAN), além do arquiteto Antônio Pedro de Alcantara ter sido o idealizador da escavação como forma de evidenciar a obra do engenheiro sueco Jacques Funk, através de hipóteses conjecturais.

(4) Em relação à abordagem do assunto, devemos agradecer as valiosas contribuições da Professora Dra. Élide Monzeglio nas discussões do seminário da disciplina de pósgraduação da FAUUSP, por ela coordenada, "Espaço Visual Experimental", no segundo semestre de 1991, e da professora Dra. Arquiteta Ana Maria Belluzo, (História/FAUUSP) e a Professora Dra. Arquiteta Denise B. Pinheiro Machado (Urbanismo/FAU-UFRJ) que em muito enriqueceram a respectiva síntese.

(5) Lynch, Kevin. La imagem de la ciudad. Buenos Aires: ed. Infinito, Biblioteca de Planeamiento y Vivienda, 1970, v. 9. p. 10.

(6) Lynch, Kevin op. cit. (...) "A doce sensação do lar é mais forte quando dito lar não é tão somente familiar e sim - também - caracterizado". (p. 13).

(7) A propósito - e com grande propriedade - escreve K. Lynch: (...) "um cenário físico vivido e integrado, capaz de gerar uma imagem nítida, desempenha assim mesmo uma função social. Pode proporcionar a matéria-prima para os símbolos e lembranças coletivas de comunicação do grupo / imaginário coletivo /. Uma paisagem atraente é o esqueleto que muitos povos aproveitam para poder erguer seus mitos de importância social. As lembranças em comum da "pátria-mãe" têm sido, com frequiência, os primeiros e mais imediatos pontos de contato entre os soldados durante uma guerra"... op. cit., p. 12.

(8) Pequeno Dicionário Brasileiro da Língua Portuguesa, São Paulo: Abril Cultural, 1973.

(9) Dicionário de Psicologia organizado por Norbert Sillamy, série Dicionários do Homem do Século XX, Larousse do Brasil, s/d, s/l, (p. 212).

(10) Segundo o prof. Jean Delay é necessário em psicologia distinguir três tipos de memória:

1. MEMÓRIA SENSÓRIO-MOTORA/ pauta-se exclusivamente pelas sensações e os movimentos, sendo comum ao animal e ao ser humano;

2. MEMÓRIA AUTISTA/AUTÍSTICA/ toma emprestado o seu material às sensações, às situações vividas, mas que não obedece senão às leis do inconsciente. E a matériaprima dos sonhos, e nos doentes mentais, do delírio: $O$ passado não é mais reconhecido como tal, mas vivido como presente.

3. MEMÓRIA SOCIAL/ O nível mais elevado, pertinente ao homem que vive em sociedade, e se caracteriza pelo discurso lógico. (Dicionário de Psicologia - op. cit. p. 212) 
(11) Foucault, Michel. L'Archeologie Du Savoir, citado por Marina Waissman em "La Estructura Historica del Entorno". Buenos Aires: Nueva Vision, 1972.

(12) As pesquisas experimentais que tem por base a fixação e a retenção de lembranças são extremamente numerosas. Elas permitem precisar certos aspectos desse problema.

Estas pesquisas concordam em afirmar que guarda-se bem:

1. aquilo que nos toca diretamente (o primeiro amor, um fato doloroso, etc.);

2. aquilo que é antes agradável do que desagradável;

3. o que está de acordo com nossas convicções;

4. aquilo que se deve lembrar porque é importante.

Ao contrário, se esquece facilmente;

1. o que é neutro;

2. o que é mal estruturado ou de estruturação confusa ou muito complexa;

3. o que é pouco significativo.

(13) A este propósito escreve Pushkin, V. N. ... "Tanto o animal como o homem, quando agem com uma determinada finalidade conduzente a um objetivo constróem mentalmente o análogo dessa finalidade e do seu movimento ao adjetivo. Ditos análogos interiores dos objetos do Mundo Exterior, denominando-se "modelos". termo comumente usado com diferentes significados. Em nosso caso a palavra é usada para designar ao "substituto do Mundo Exterior". Dito "modelo" permite realizar certa concatenação de operações como podem ser representadas no diagrama de fluxo anexo."

Estes "modelos", segundo Pushkin, não se apresentam na mente do animal ou do homem na forma de um objeto "real" "parece mais tratar-se de um "sistema" de desenhos - ou melhor, sistemas de representação, como utiliza Alan Colqhoun ou Claude Levi-Strauss - que refletem as propriedades essenciais dos objetos reais com os quais, porém, podem ser realizadas mentalmente operações como se fossem objetos reais.

Neste ponto que reside a diferença com outras conceituações de "modelos": este é um "Modelo Informacional " (Cognitivo) do Cérebro.

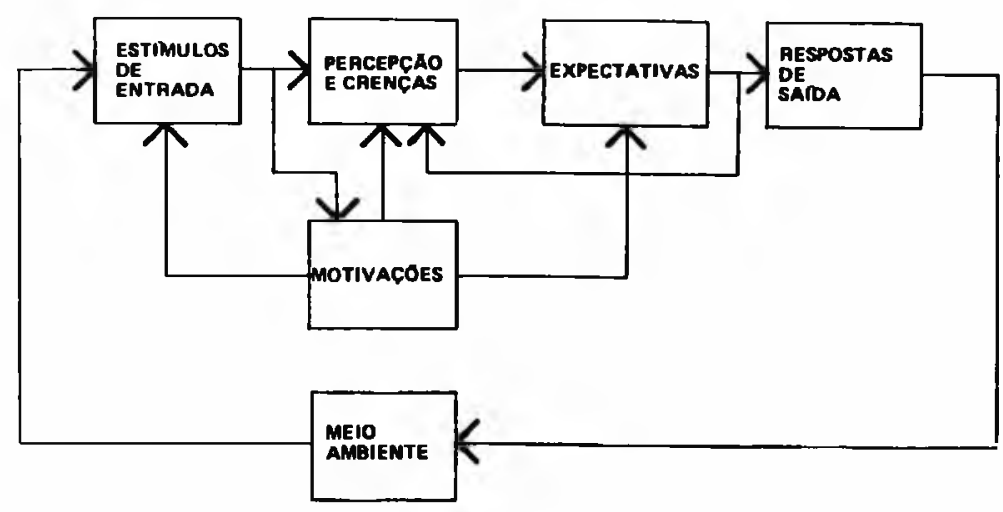

MODELO COSNITIVO CONDICIOMANTE DO MODELO INTERMALIZADO DO MUNDO EXTERIOR FORMADO PELO ARQUITETO. 
(14) Como afinna Glusberg, J. ... "A concepção derivada da colocação topológica do homo habitans influi poderosamente nas suas relações concretas com os demais homens. e sua imagem da natureza e de suas representações sobre ele mesmo"... (p. 27) (op. cit.) (15) A questão do registro imaginário, amplamente tratada e desenvolvida pela teoria psicoanalítica de Jacques Lacan, não é inédita dado que já se encontrava embutida nas reflexões de um dos mais importantes filósofos do racionalismo, Baruj Spinoza (16321677), para quem o imaginário deriva das relações de imediatez entre o Homem e o Mundo, por um lado, e o Homem e os Signos, por outro.

(16) De fato, como afirma A. Moles (p. 116)... "mais que estabelecer noçōes isoladas. uma das "dérmarche" mais produtivas do pensamento filosófico consiste em pôr em evidência, na rede conceitual, bipolaridades dialéticas entre as quais se orienta a atividade criadora do espírito"...

(17) Verifica-se, assim, a assertiva de A. Moles ao interpretar a forma como... "uma correlação do sinal consigo mesmo... deixando no vago o que não pertence à forma, qualificado simplesmente de "diferente"... (p. 116).

(18) Ou seja... "não existe nenhuma diferença de estrutura absoluta entre perturbações e sinal: ambos são da mesma natureza... Um ruído é um sinal que não "se" quer transmitir" (p. 120).

(19) MOLES, A. op. cit. p. 123.

(20) MC LUHAN, Marshall. As idéias de Mc Luhan por Jonathan Miller. Série Mestres da Modernidade. São Paulo: Ed. Cultrix, 1973.

(21) Assim, a "estrutura-suporte-museu" comporta-se como um (...) "operador semantico que se comporta como receptáculo de outros signos e outras mensagens... $\mathrm{O}$ "museusigno" ou "museu-mensagem", nos conduz a tratá-lo como uma entidade comunicacional, por excelência, muito além dos conteúdos físicos que apresente". (...) (Glusberg, J., op. cit. p. 14-16).

(22) ... "Na várzea, ao longo da orla, um primeiro caminho sobre faixa ressecada conectava o Castelo ao morro de São Bento, assim conhecido após a construçāo em suas encostas, no início do séc. XVII, do mosteiro beneditino de mesmo nome.

Esse caminho se compunha, basicamente, das duas principais ruas do Rio colonial as ruas Misericórdia e Direita e se articulava à primeira praça formada na várzea o terreiro, posteriormente largo do Carmo, assim chamado devido aos edifícios delimitando seu lado oeste, o convento carmelita e sua igreja e a igreja da Ordem Terceira do Carmo. Seu prolongamento era a ladeira de São Bento, conduzindo ao mosteiro de mesmo nome.

A partir desse caminho a cidade ocupou a planície limitada ao sul pelos morros do Castelo e de Santo Antônio e, ao norte, pelos morros de São Bento e de Nossa Senhora da Conceição."... Sisson, Rachel, op. cit. p. 58.

(23) ABREU, Maurício. citado por CENIQUEL, Mario, op. cit. p. 90.

(24) A centralidade investida no morro do Castelo por intermédio dos marcos edificados tipologicamente diferenciados que o coroavam veio, assim, a diluir-se, e, por quase dois séculos - como a autora procurou demonstrar em Arquitetura, Religiāo e Urbanizaçāo , a cidade dependeu de seus marcos religiosos -, tipologicamente afins, porém espacialmente dispersos -, como principais elementos instauradores de centralidade, 
situaçäo que perdurou até a segunda metade do séc. XVIII, quando novo centro se formou. SISSON, Rachel, op. cit. p. 58.

(25) Às vésperas do término do período colonial o antigo largo do Carmo era uma "praça nua, composta na melhor tradição e apropriada à formatura militar", tal como a representou Leandro Joaquim em uma de suas telas ovais. Revista Militar no Largo do Paço.

Nessa tela, o primeiro plano do largo é ocupado pelo cais, duplamente significativo enquanto elemento defensivo - de função análoga à da bateria de canhões anteriormente disposta à beira-mar, no próprio largo e como limite entre terra e mar no local consagrado de acesso à cidade-sede do poder colonial, e, nessa condiçāo, ponto inieiallterminal privilegiado de trocas entre a metrópole e a colônia. SISSON, Rachel. op. cit. p. 59.

(26) Poder-se-ia ainda acrescentar a esses aspectos o uso da área junto ao cais como opção rotineira para o lazer cotidiano, por ser passatempo favorito dos pequenos capitalistas e comerciantes o comparecimento ao local após o jantar, nas horas finais do entardecer, tal como documentado por Debret, já em princípios do Oitocentos. Sisson, Rachel. op. cit. p. 59.

(27) Sisson, Rachel. op. cit. p. 60.

(28) Essa comparação pode ser reforçada pelo confronto da inserção urbanística da praça do Palácio o largo do Paço, antigo largo do Carmo, do Rio de Janeiro com a do terreiro do Paço, de Lisboa.

A baixada lisboeta era delimitada ao sul pelo rio Tejo, a leste pelas colinas de São Jorge e, a oeste, pela de São Francisco, sendo a trama viária irregular que a recobria substituída, após o terremoto de 1775 , por traçado ortogonal, enquadrando o grande terreiro à beira-rio.

Configuração semelhante existiu no Rio de Janeiro, com a várzea localizada entre os alinhamentos dos morros do Castelo e Santo Antonio, ao sul, de São Bento e Nossa Senhora da Conceição, ao norte e pelo litoral a leste, junto ao qual se abria o largo do Paço.

Para as respectivas áreas as duas praças atuaram como cores; em escala muito mais ampla, se o terreiro, às margens do Tejo, representou Lisboa como sede do Império ultramarino português, o largo do Paço, afirmou, para esse mesmo universo, a condição do Rio de Janeiro de importante subcentro metropolitano. SISSON Rachel. op. cit. p. 62. (29) LAURIE, Michael. op. cit, p. 230, 237.

\section{BIBLIOGRAFIA}

ABREU, Maurício de A. Evolução urbana do Rio de Janeiro. Rio de Janeiro: IPLANRIO, Ed. Jorge Zahar, 1987.

ARHEIM, Rudolf. Arte y percepción visual: psicologia de la vision creadora. Buenos Aires: EUDEBA, 1962. 
CENIQUEL, Mario, "Paisagem e Habitat" In: Paisagem e Ambiente Ensaios IV São Paulo: FAUUSP. 1992.

A prática arquitetônica como forma de elaboração de uma crítica arquitetônica. São Paulo, 1990. Dissertação (Mestrado) - FAUUSP.

COLHOUN, Alan. Tipologia y método de diseño. In: JENCKS, C. e BAIRD, G. El significado en arquitectura. Madrid: Blume, $1^{\mathrm{a}}$ ed. espanhola, 1975.

CORBIN, Alain. O território do vazio; A praia e o imaginário ocidental. São Paulo: Cia. das Letras, 1989.

CORREDOR CULTURAL: Como recuperar, reformar ou construir seu Imóvel. RIOARTE-IPLANRIO. Rio de Janeiro: Prefeitura da cidade do Rio de Janeiro, 1989. $2^{3}$ ed.

Dicionário de Psicologia, organizado por Norbert Sillamy, Série "Dicionário do homem do século XX", Ed. Larouse do Brasil, s/d. s/l.

ECO, Umberto. Obra aberta. Série Estática, São Paulo: Perspectiva, Coleção Debates, 1976.

FERREZ, Gilberto. O paço da cidade do Rio de Janeiro. Rio de Janeiro: MEC/SPHAN Pró-memória. 1985.

FOUCAULT, Michel. "L'Archeologie du Savoir", citado por WAISMAN, Marina. In: La estructura histórica del entorno. Buenos Aires: Nueva Visión, 1972.

GILLAM SCOTT, Robert. Fundamentos del diseño. Buenos Aires: Victor Lerú, 1967.

GLUSBERG, Jorge. Hacia una crítica de la arquitectura. Buenos Aires: Espacio, 1980.

KHUN, Thomas S. A estrutura das renovaçōes científicas. São Paulo: Perspectiva, Coleção Debates, 1987.

LAURIE, Michael. Introducción a la arquitectura del paisaje, colección arquitectural perspectivas. Barcelona: G. Gili, 1983.

LEVI-STRAUSS, Claude. Antropologia Estructural. Buenos Aires: EUDEBA, 1968.

LYNCH, Kevin. La imagen de la ciudad. Buenos Aires: Ediciones Infinito, Biblioteca de Planeamiento y Vivienda. v. 9, 1970. $2^{\mathrm{a}}$ ed. en castellano.

McLUHAN, Marshall. As idéias de McLuhan por Jonathan Miller. Série mestres da Modernidade. São Paulo: Cultrix, 1973.

MOLES, Abraham. Teoria da informaçāo e percepçāo estética. Rio de Janeiro: Tempo Brasileiro, 1969.

PEQUENO DICIONÁRIO BRASILEIRO DA LÍNGUA PORTUGUESA. São Paulo: Abril Cultural, 1973. 
PIERCE Charles Sanders. Collected papers. In: Semiótica e Filosofia. Textos escolhidos e traduzidos por O. Silveira da Mota e L. Hegenberg. São Paulo: Cultrix, 1985.

PIGNATARI, Décio. Informaçāo, linguagem e comunicaçāo. São Paulo: Cultrix, 1982.

PUSHKIN, Vladimir N. Psicologia Y Cibernética. Barcelona: Planeta. Laboratório de Heurística do Instituto de Psicologia e Pedagogia da Academia de Ciências de Moscou. 1974.

SISSON, Rachel. Marcos histónicos e configurações espaciais/Um estudo de caso: os centros do Rio de Janeiro. In: Arquitetura Revista n. 4, p. 57/81, FAU-UFRJ, Rio de Janeiro, 2º semestre 1986.

THOMAS, Keith. O homem e o mundo natural: Mudança de atitude em relação às plantas e aos animais (1500-1800). São Paulo: Cia. das Letras, 1988. 